\title{
Dietary sources of energy and nutrients in the contemporary diet of Invit adults: results from the 2007-08 Inuit Health Survey
}

\author{
Tiff-Annie Kenny ${ }^{1}$, Xue Feng Hu ${ }^{1}$, Harriet V Kuhnlein ${ }^{2,3}$, Sonia D Wesche ${ }^{4}$ and \\ Hing Man Chan ${ }^{1}$,* \\ 'Department of Biology, University of Ottawa, 30 Marie Curie, Ottawa, ON, Canada, K1N 6N5: ${ }^{2}$ Centre for \\ Indigenous Peoples' Nutrition and Environment, McGill University, Montreal, QC, Canada: ${ }^{3}$ School of Dietetics and \\ Human Nutrition, McGill University, Montreal, QC, Canada: ${ }^{4}$ Department of Geography, Environment and \\ Geomatics, University of Ottawa, Ottawa, ON, Canada
}

Submitted 20 June 2017: Final revision received 7 November 2017: Accepted 16 November 2017: First published online 14 January 2018

\begin{abstract}
Objective: To characterize the major components of the contemporary Inuit diet and identify the primary sources of energy and essential nutrients.

Design: Dietary data were derived from the $24 \mathrm{~h}$ recall collected by the Inuit Health Survey (IHS) from 2007 to 2008. The population proportion method was used to determine the percentage contribution of each group. Unique food items/ preparations (ninety-three country foods and 1591 market foods) were classified into eight country food groups and forty-one market food groups. Nutrient composition of each food item was obtained from the Canadian Nutrient File. Setting: Thirty-six communities across three Inuit regions of northern Canada.

Subjects: A representative sample ( $n$ 2095) of non-pregnant Inuit adults $(\geq 18$ years), selected through stratified random sampling.

Results: Despite their modest contribution to total energy intake (6.4-19.6\%, by region) country foods represented a major source of protein (23-52\%), Fe (28-54\%), niacin (24-52\%) and vitamins D (up to $73 \%), \mathrm{B}_{6}(18-55 \%)$ and $\mathrm{B}_{12}$ (50-82\%). By contrast, the three most popular energy-yielding market foods (i.e. sweetened beverages, added sugar and bread) collectively contributed approximately $20 \%$ of total energy, while contributing minimally to most micronutrients. A notable exception was the contribution of these foods to $\mathrm{Ca}$ (13-21\%) and vitamins E (17-35\%) and C (as much as 50\%). Solid fruits were consumed by less than $25 \%$ of participants while vegetables were reported by $38-59 \%$ of respondents.

Conclusions: Country foods remain a critical dimension of the contemporary Inuit diet.
\end{abstract}

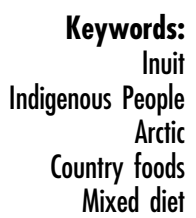

From the Arctic to the South Pacific, Indigenous Peoples have experienced a rapid nutrition transition ${ }^{(1,2)}$ characterized by the adoption of a 'western' diet (i.e. high in saturated fats, sugar and processed foods) and the decline of traditional/subsistence-based ways of life ${ }^{(3-6)}$. Across the globe, this dietary shift has been paralleled by an increase in the prevalence of obesity, diabetes and other diet-related chronic diseases ${ }^{(3-6)}$. Inuit are a traditionally semi-nomadic Indigenous Peoples residing across the circumpolar north $^{(7)}$. In the latter half of the 20th century, Inuit endured significant lifestyle changes, involving the settlement into permanent communities, the development of a wage economy and the introduction of market foods to remote northern communities ${ }^{(8)}$. The diet transition among Inuit is characterized by the decreased consumption of 'country foods' (foods harvested from northern ecosystems, through cultural practices, traditions and detailed environmental knowledge) and the increased presence of 'market foods' (foods shipped to northern communities from the south and purchased in stores) in the $\operatorname{diet}^{(5,9,10)}$.

The harvest and consumption of country foods remain fundamental to Inuit cultural identity ${ }^{(11-13)}$, food security and dietary adequacy ${ }^{(14-16)}$. However, the transition towards higher intakes of market foods has led to excessive intakes of energy, carbohydrates and fat, coupled with inadequate intakes of several micronutrients (i.e. dietary fibre, $\mathrm{Ca}$, folate and vitamins $\mathrm{A}, \mathrm{D}$ and $\mathrm{E})^{(5,9,10,17,18)}$. This transition is associated with high rates of food insecurity ${ }^{(10)}$, has been linked to increasing incidence of obesity, and bears important risks for the development of diabetes and chronic disease ${ }^{(5,19)}$. 
Inuit experience moderate and/or severe food insecurity at almost four times the rate of non-Aboriginal Canadians ( $27 \%$ relative to $7 \%$, based on data from males aged 12 years or older) ${ }^{(20)}$.

With few exceptions, research on the Inuit diet in Canada generally consists of community-level studies, involving small sample sizes. While there are unique qualities that define Inuit communities at the local level, food system disturbances (e.g. environmental change) are often expressed, and modelled by scientists, at larger scales $^{(21)}$. Likewise, strategies and interventions to improve food security and nutrition in Inuit communities may necessitate broader regional, territorial or federal support (see, for example, the federally administered Nutrition North Canada Program ${ }^{(22)}$ and the Nunavut Food Security Strategy and Action Plan ${ }^{(23)}$.

Kuhnlein et al. (2008) provide a comprehensive description of dietary adequacy in three populations of Arctic Indigenous adults ( $n$ 3329) across Canada between 1993 and $1999^{(24)}$. More recently, several authors have reported diet, nutrition and food security results from the 2007-08 International Polar Year Inuit Health Survey (IHS) ${ }^{(10,19,25-27)}$. The IHS was developed in response to the disparity in available information regarding the health status of Inuit residing across the Canadian Inuit Nunangat (homeland of Inuit of Canada). The IHS collected comprehensive baseline data for 2595 Inuit adults in thirty-six communities, spanning three jurisdictions of Inuit
Nunangat (Nunatsiavut, Nunavut and the Inuvialuit Settlement Region (ISR); Fig. 1). Health status for Inuit in Nunavik (the fourth Inuit region in Canada) was assessed during the 2004 Qanuippitaa? How are we? Nunavik Health Survey ${ }^{(28)}$.

The purpose of the present study was to describe region-level population diets for a large sample of Inuit adults across the Canadian north. Specifically, our objectives were to: (i) identify principal dietary sources of energy and selected nutrients; and (ii) examine the relative contribution of country foods and market foods to energy and nutrient intakes.

\section{Methods}

\section{Study design and sample}

Dietary data were derived from the Canadian International Polar Year IHS. The IHS, conducted between the late summer/autumn of 2007 and 2008, collected comprehensive baseline data about the health and living conditions of Inuit adults across three Inuit regions (Nunatsiavut, Nunavut and the ISR) spanning the Canadian north (latitude of $54^{\circ} 10^{\prime} \mathrm{N}$ to $76^{\circ} 25^{\prime} \mathrm{N}$ ). Complete methodology and design for the 2007-08 IHS have been published elsewhere ${ }^{(29)}$.

The survey was cross-sectional, employing a stratified random sampling of households in thirty-three coastal

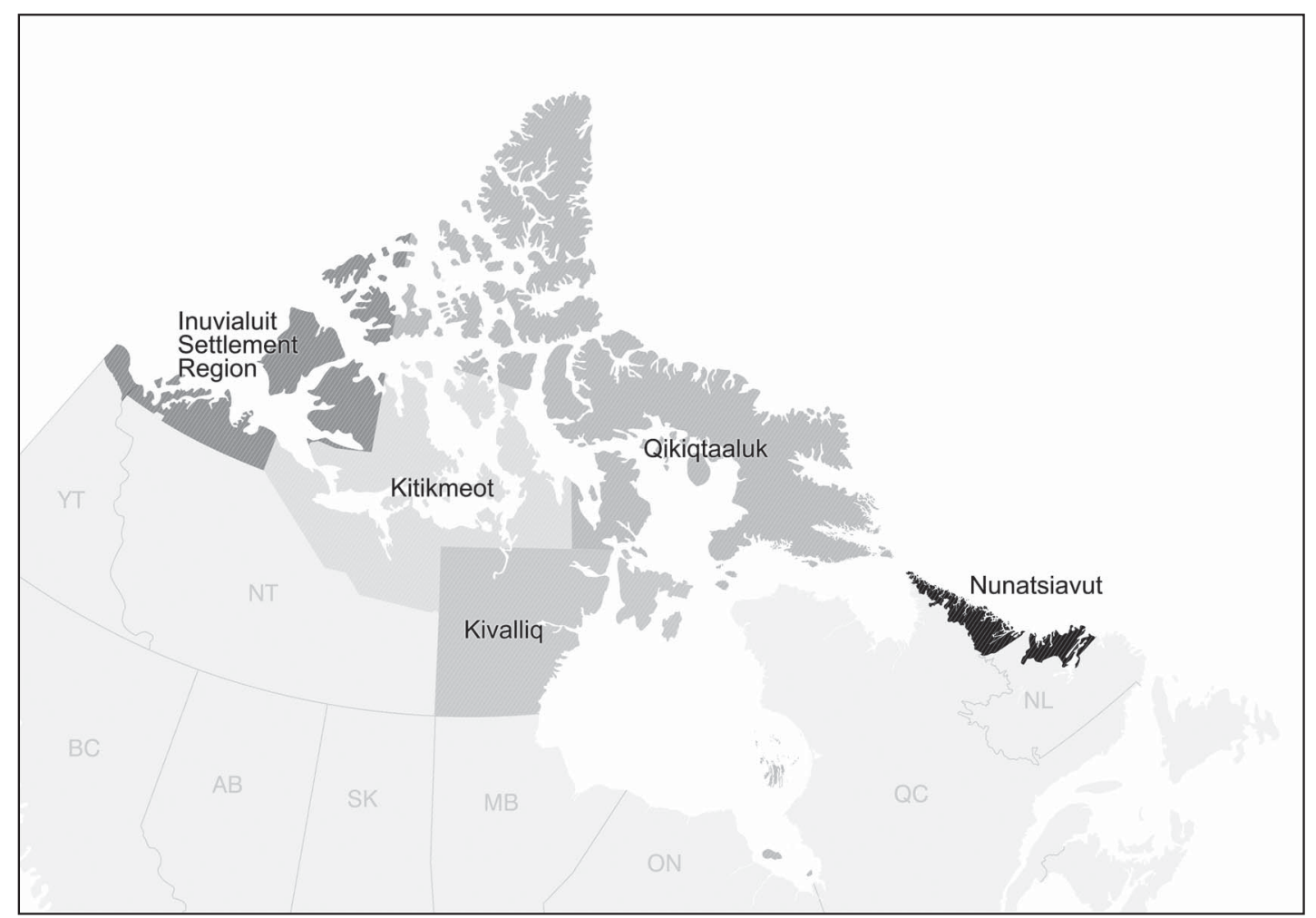

Fig. 1 Map of the participating Inuit regions* of the 2007-08 Inuit Health Survey. *Nunavut is comprised of the Kitikmeot, Kivalliq and Qikiqtaaluk regions 
communities and three inland communities (Fig. 1). A total of 2796 households were randomly selected to participate. From the households, non-pregnant Inuit adults aged 18 years or older were eligible to participate.

\section{Dietary assessment}

As described elsewhere ${ }^{(10,15)}$, dietary assessments were conducted in-person by trained interviewers in English and Inuit Languages. Diet was assessed by administering a single $24 \mathrm{~h}$ dietary recall (beginning at midnight and ending at midnight), based on an adapted form of the US Department of Agriculture's (USDA) Automated MultiplePass method ${ }^{(30)}$. Three-dimensional graduated food model kits ${ }^{(31)}$ were available to aid participants in the estimation of portion sizes. Due to survey logistical constraints, a single $24 \mathrm{~h}$ recall was collected from each participant. While this method does not capture interindividual variations in dietary intake, it is appropriate for estimating population mean intakes ${ }^{(32)}$. Dietary data were entered using CANDAT Software (Godin London Inc.).

A total of 1591 (including ninety-three country foods) unique food and beverage (hereafter referred to as 'food(s)') items and/or preparations, corresponding to unique food codes in the Canadian Nutrient File (CNF), were reported in the dietary recalls. Alcoholic beverages (twelve unique items), which are legislatively prohibited in some Inuit communities, were excluded from all analyses. All foods and beverages reported as consumed in the IHS were coded hierarchically, by item similarity and food group (major and sub groups; see online supplementary material, Supplemental Tables 1 and 2). Similar food items in each recall were collapsed into a single item (e.g. 'potato chips' aggregated all potato chips of various seasonings) and compiled as a daily sum for the item $(\mathrm{g} /$ person per $\mathrm{d})$. Food groups were based on the classification scheme of the USDA's Food and Nutrient Database for Dietary Studies (FNDDS) 5.0 (33), with some exceptions to reflect culinary usage (e.g. butter was categorized as a 'fat and oil' as opposed to a dairy product) and the dietary habits of Inuit. Due to database limitations, foods reported as mixed dishes/recipes (e.g. pizza, sandwiches) could not be disaggregated into component ingredients. Thus, a 'mixed dishes' grouping was included and classified according to the dish's primary ingredients (e.g. primarily meat dishes; primarily grain dishes). Potatoes were excluded from the vegetables grouping and included with 'grains and starches'. Efforts were made to group market foods based on nutritional similarities (e.g. high-sugar beverages, such as fruit drinks and cola, were collectively grouped). However, food fortification practices in Canada ${ }^{(34)}$, such as the mandatory fortification of flour (with thiamin, riboflavin, niacin, folic acid and Fe), as well as the fortification of fruit-flavoured drinks with vitamin C (mandatory), folic acid (voluntary) and Fe (voluntary), can complicate these relationships.
Country foods were classified by species (e.g. caribou, beluga whale) and body part (e.g. meat, fats, organs). Bannock, a homemade biscuit (often considered traditional), was included with market grains and starches. The importance of food items/subgroups to total diet was characterized by: (i) mean population consumption (averaged for all participants, by region); and (ii) the percentage of recalls reporting consumption of a particular food.

\section{Dietary sources of energy and nutrients}

The CNF national food composition database ${ }^{(35)}$ was used to calculate energy and nutrient intakes. Nutrient composition information for foods not included in the CNF was available from an additional in-house food file (McGill School of Dietetics and Human Nutrition), as described elsewhere ${ }^{(10)}$. Missing nutrient values for all foods were imputed following procedures described by Schakel et al. ${ }^{(3)}$. The USDA FNDDS 5.0 was used to supplement missing nutrient information for market foods ${ }^{(33,37)}$. Missing nutrient values for country foods (not in the FNDDS) were imputed and/or calculated manually, based on similar food items (considering the species, body part and preparation method).

\section{Analysis}

Data management and statistical analyses were performed with SAS statistical software package version 9.4. The percentage contribution of each food subgroup to total energy and nutrient intakes was calculated for the entire population, according to the population proportion method ${ }^{(38,39)}$. Nutrients analysed include energy, selected macronutrients (protein, fat, carbohydrates, total sugar, saturated fat), dietary fibre, vitamins (A, C, D, E, B $\mathrm{B}_{12}$, thiamin, riboflavin) and minerals $(\mathrm{Ca}, \mathrm{Fe}, \mathrm{Mg}, \mathrm{Zn}, \mathrm{Cu}, \mathrm{Se}, \mathrm{Na})$. Dietary supplements, which were consumed by $<10 \%$ of all IHS respondents (IHS, unpublished results), were not included in the calculation of total nutrient intakes.

\section{Results}

A total of 2595 Inuit adults ( 1.3 participants per household) agreed to participate in the IHS. Complete $24 \mathrm{~h}$ dietary recalls were available from a total of 2097 participants (1292 women and 805 men). Characteristics of the study sample are summarized in Table 1 . The mean age of participants was 43 (SD 15) and 41 (SD 15) years for men and women, respectively. The mean BMI for men was $27 \cdot 2$ (SD 5.5$) \mathrm{kg} / \mathrm{m}^{2}$ and $29 \cdot 2(\mathrm{SD} 7.0) \mathrm{kg} / \mathrm{m}^{2}$ for women, both of which fall within the 'overweight' class (BMI $=25-30 \mathrm{~kg} / \mathrm{m}^{2}$ ) defined by WHO. The mean energy intake was 9837 (sD 5669) kJ/d (2351 (sD 1355) kcal/d) for men and 8209 (sD 4301) kJ/d (1962 (sD 1028) kcal/d) for women.

\section{Top food items}

Across all regions, the most frequently consumed country foods, in terms of percentage of recalls that reported the 
Table 1 Characteristics of the study sample of Inuit adults ( $n$ 2095), by region; Inuit Health Survey, 2007-2008

\begin{tabular}{|c|c|c|c|c|c|c|c|c|c|}
\hline & \multicolumn{3}{|c|}{ Nunavut } & \multicolumn{3}{|c|}{ Inuvialuit Settlement Region } & \multicolumn{3}{|c|}{ Nunatsiavut } \\
\hline & $\begin{array}{c}\text { Total } \\
(n \text { 1568) }\end{array}$ & $\begin{array}{c}\text { Men } \\
(n \text { 620) }\end{array}$ & $\begin{array}{l}\text { Women } \\
(n \text { 948) }\end{array}$ & $\begin{array}{c}\text { Total } \\
(n \text { 267) }\end{array}$ & $\begin{array}{c}\text { Men } \\
(n 86)\end{array}$ & $\begin{array}{l}\text { Women } \\
(n \text { 181) }\end{array}$ & $\begin{array}{l}\text { Total } \\
(n \text { 260) }\end{array}$ & $\begin{array}{l}\text { Men } \\
(n \text { 97) }\end{array}$ & $\begin{array}{l}\text { Women } \\
(n \text { 163) }\end{array}$ \\
\hline \multicolumn{10}{|l|}{ Age (years) } \\
\hline Mean & $40 \cdot 7$ & 41.5 & $40 \cdot 1$ & $44 \cdot 2$ & $46 \cdot 9$ & $42 \cdot 9$ & $44 \cdot 3$ & $46 \cdot 0$ & 43.2 \\
\hline SD & $14 \cdot 7$ & 14.6 & 14.7 & $15 \cdot 8$ & $15 \cdot 6$ & $15 \cdot 8$ & 13.9 & $15 \cdot 5$ & $12 \cdot 8$ \\
\hline$<40$ years $(\%)$ & 51.4 & 49.4 & 52.7 & 38.6 & $30 \cdot 2$ & 42.5 & 35.4 & $32 \cdot 0$ & 37.4 \\
\hline$\geq 40$ years $(\%)$ & $48 \cdot 6$ & $50 \cdot 6$ & $47 \cdot 3$ & 61.4 & $69 \cdot 8$ & 57.5 & 64.6 & $68 \cdot 0$ & $62 \cdot 6$ \\
\hline \multicolumn{10}{|l|}{ BMI $\left(\mathrm{kg} / \mathrm{m}^{2}\right)$} \\
\hline Mean & $27 \cdot 9$ & $26 \cdot 9$ & 28.7 & $30 \cdot 5$ & 28.9 & $31 \cdot 2$ & $29 \cdot 3$ & $27 \cdot 9$ & $30 \cdot 1$ \\
\hline $\mathrm{BMI}=25-29.99 \mathrm{~kg} / \mathrm{m}^{2}(\%)$ & $26 \cdot 3$ & 31.9 & 22.5 & $26 \cdot 7$ & 32.5 & $24 \cdot 0$ & 33.5 & $35 \cdot 4$ & $32 \cdot 3$ \\
\hline $\mathrm{BMI} \geq 30 \mathrm{~kg} / \mathrm{m}^{2}(\%)$ & $33 \cdot 1$ & 24.0 & 39.1 & $49 \cdot 0$ & $41 \cdot 3$ & $52 \cdot 6$ & 41.2 & 31.3 & $47 \cdot 2$ \\
\hline \multicolumn{10}{|l|}{ Diet energy } \\
\hline \multicolumn{10}{|l|}{ Total diet energy* $(\mathrm{kJ} / \mathrm{d})$} \\
\hline Mean & 8753 & 9740 & 8104 & 9766 & 11263 & 9054 & 8376 & 9188 & 7891 \\
\hline SD & 5657 & 5674 & 5644 & 523 & 531 & 519 & 402 & 414 & 393 \\
\hline \multicolumn{10}{|l|}{ Total diet energy* (kcal/d) } \\
\hline Mean & 2092 & 2328 & 1937 & 2334 & 2692 & 2164 & 2002 & 2196 & 1886 \\
\hline SD & 1352 & 1356 & 1349 & 125 & 127 & 124 & 96 & 99 & 94 \\
\hline \multicolumn{10}{|c|}{ Total diet energy from country foods $†(\%)$} \\
\hline Among participants $<40$ years & $12 \cdot 5$ & $14 \cdot 6$ & 11.2 & $6 \cdot 5$ & $8 \cdot 1$ & $6 \cdot 0$ & $2 \cdot 7$ & $2 \cdot 8$ & $2 \cdot 7$ \\
\hline Among participants $\geq 40$ years & $25 \cdot 6$ & $27 \cdot 6$ & $24 \cdot 1$ & $19 \cdot 2$ & $21 \cdot 7$ & $17 \cdot 8$ & $9 \cdot 3$ & $13 \cdot 0$ & $6 \cdot 8$ \\
\hline
\end{tabular}

*Total diet energy excludes consumption of alcohol.

†Country foods are wild foods harvested locally through cultural practice, traditions and knowledge.

item, were caribou (18-39\%, by region) and fish (7-22\%, by region; Table 2). Consumption of country food meat was reported by nearly half $(47.6 \%)$ of all participants in Nunavut, about a third $(34.8 \%)$ of participants in the ISR and almost a quarter of all participants (24.6\%) in Nunatsiavut (Table 2). A notable difference in the consumption of country food fat was observed between regions $(22 \%$ of respondents in Nunavut and approximately $1 \%$ of respondents in Nunatsiavut), coincident with the consumption of marine mammals (Table 2).

The most frequently reported market food items were coffee and tea (>85\% of recalls), (granulated) sugar (>65\% of recalls), sweetened beverages (44-64\% of recalls) and bread (50-80\% of recalls; Table 3). Consumption of dairy products was reported by the majority of participants (62-72\%, by region), but region-level differences were observed in the consumption of fluid milk $v$. powdered milk and non-dairy coffee whitener, with higher consumption of the former in Nunatsiavut. Store-bought meats (including other proteins) were reported by $68-90 \%$ of participants, according to region. Solid fruits were consumed by less than $25 \%$ of participants across all regions (Table 3), while solid vegetables (onions, carrots and other root vegetables) were reported by $38-59 \%$ of respondents on the day prior to the interview.

\section{Top dietary sources of energy and nutrients}

The top ten food sources of dietary energy and nutrients, including the percentage contribution of each food to total intake, are presented by region in Tables 4-6.
Contribution of country foods to dietary intake

The contribution of country foods to total diet energy (TDE) for individuals ranged between $0 \%$ TDE (43.5\% of all respondents) to over $50 \% \operatorname{TDE}(10.0 \%$ of all respondents), with less than $1 \%$ of respondents consuming $90 \%$ or more of TDE from country foods (data not presented). The contribution of country foods to TDE for the population differed by region, and was stratified by sex and age (Table 1). In general, the contribution of country foods to TDE was lowest in Nunatsiavut, particularly among younger ( $<40$ years) adults $(2.7 \%)$, and highest in Nunavut, particularly among older ( $\geq 40$ years) adults (25.6\%).

At the regional level, country foods represented a modest contribution to total diet (6.4-19.6\% TDE), but were a major source of many nutrients across all regions (Figs 2 and 3). Country foods contributed significantly to protein (23-52\%), with caribou ranking among the top two sources of protein in all regions (Table 4). Country foods were a principal source of many micronutrients (Fig. $3)$, namely Fe (28-54\%), niacin (24-52\%) and vitamins D (73\% in both Nunavut and the ISR), $\mathrm{B}_{6}(18-55 \%)$ and $\mathrm{B}_{12}$ (50-82\%).

The majority of total fat $(>75 \%)$ and saturated fat ( $>80 \%$ ) was provided by market foods (Table 4 ); however, country foods were a major source of cholesterol (19.6-47.3\%; Fig. 2). Country foods collectively contributed less than 20-25\% of total MUFA in Nunavut and the ISR (Fig. 2), with beluga ranking as the principal source of MUFA in both regions (7-8\% of total intake; data not presented). Country foods contributed $18.5 \%$ of PUFA in Nunavut and $13.6 \%$ in the ISR (Fig. 2), which were 
Table 2 Mean* consumption (g/person per d) of country foods by adult Inuit respondents of the $24 \mathrm{~h}$ recall $(n$ 2095), by region; Inuit Health Survey, 2007-2008

\begin{tabular}{|c|c|c|c|c|c|c|c|c|c|}
\hline \multirow[b]{2}{*}{ Country food } & \multicolumn{3}{|c|}{ Nunavut ( $n$ 1568) } & \multicolumn{3}{|c|}{ Inuvialuit Settlement Region ( $n$ 267) } & \multicolumn{3}{|c|}{ Nunatsiavut (n 260) } \\
\hline & $\%$ of recalls & Mean & SD & $\%$ of recalls & Mean & SD & $\%$ of recalls & Mean & SD \\
\hline \multicolumn{10}{|l|}{ By part } \\
\hline Country food - meat $\dagger$ & $47 \cdot 6$ & $116 \cdot 4$ & 194 & $34 \cdot 8$ & $82 \cdot 4$ & 156 & 24.6 & $49 \cdot 6$ & 124 \\
\hline Country food - fatł & $21 \cdot 6$ & $45 \cdot 7$ & 134 & $12 \cdot 4$ & $25 \cdot 7$ & 142 & $1 \cdot 2$ & 0.3 & 4 \\
\hline Country food - organs§ & $2 \cdot 1$ & $2 \cdot 0$ & 25 & $2 \cdot 2$ & 1.9 & 16 & 1.5 & 0.7 & 7 \\
\hline \multicolumn{10}{|l|}{ By animal/species } \\
\hline Birds & 1.5 & $3 \cdot 1$ & 29 & $5 \cdot 2$ & $11 \cdot 7$ & 68 & $5 \cdot 0$ & $10 \cdot 4$ & 59 \\
\hline Fish (country food only) & $14 \cdot 3$ & $42 \cdot 9$ & 143 & $22 \cdot 1$ & $61 \cdot 8$ & 153 & $7 \cdot 3$ & $20 \cdot 1$ & 104 \\
\hline Caribou & $39 \cdot 3$ & $97 \cdot 4$ & 187 & $29 \cdot 2$ & $68 \cdot 1$ & 144 & $18 \cdot 1$ & $36 \cdot 0$ & 109 \\
\hline Other land mammals & 1.5 & $2 \cdot 8$ & 28 & $1 \cdot 1$ & 4.9 & 50 & 0.4 & 0.3 & 5 \\
\hline Seal and walrus & $9 \cdot 1$ & $18 \cdot 4$ & 85 & $1 \cdot 1$ & 0.8 & 10 & 1.9 & 3.9 & 33 \\
\hline Beluga whale & 11.0 & $30 \cdot 6$ & 116 & $9 \cdot 7$ & 23.4 & 141 & 0.0 & 0.0 & 0 \\
\hline Narwhal & $4 \cdot 3$ & $12 \cdot 0$ & 72 & 0.7 & $1 \cdot 1$ & 13 & 0.0 & 0.0 & 0 \\
\hline Berries & $3 \cdot 1$ & $6 \cdot 2$ & 44 & 0.7 & $2 \cdot 2$ & 24 & 1.5 & 0.2 & 2 \\
\hline
\end{tabular}

*Population mean (consumers and non-consumers), by region.

†Total meat does not include fish.

$\ddagger$ Total fat includes muktuk (whale blubber and skin).

$\S$ Total organs includes bone marrow and offal.

derived principally from caribou and local fish. Country foods did not contribute significantly to carbohydrates $(<0.5 \%)$, total sugar $(<0.5 \%)$, dietary fibre $(<5 \%), \mathrm{Na}$ $(<6 \%)$ or $\mathrm{Ca}(<5 \%$; Figs 2 and 3). Country foods, likewise, did not contribute significantly to vitamin $\mathrm{C}$ in both the ISR $(10 \%)$ and Nunatsiavut $(<2 \%)$. In Nunavut, however, country foods (beluga muktuk, arctic char and local berries) collectively contributed $17 \%$ of total vitamin $\mathrm{C}$ intake (Fig. 3).

Contribution of market foods to dietary intake

Market foods accounted for the majority of TDE (80.4-93.7\%, by region). Sweetened beverages (excluding $100 \%$ fruit juices) were the primary contributor to energy in both Nunavut (11.3\% TDE) and the ISR (9.3\% TDE), and ranked third in Nunatsiavut (7.3\% TDE), after bread and potato chips (Table 4). Collectively, sweetened beverages, added sugar and bread (the three most popular market foods, after coffee and tea) contributed approximately 20\% TDE (Table 4) while contributing minimally to most micronutrients. A notable exception was the contribution of these foods to $\mathrm{Ca}$ (13.2-21.4\%) and vitamins E (17-35\%) and C (as much as $50 \%$; Tables 5 and 6). Sweetened beverages were the number one source of $\mathrm{Ca}(14-17 \%)$ in both Nunavut and the ISR, whereas milk was the major contributor to $\mathrm{Ca}$ in Nunatsiavut (25.3\%). Sweetened beverages (particularly powdered vitamin C-fortified drinks) were likewise the principal source of vitamin C in both Nunavut and the ISR, accounting for over $40 \%$ of the population's total intake (Table 5). In Nunatsiavut, vitamin C was derived principally from $100 \%$ fruit juices (44.5\%), which were consumed by $30 \%$ of the respondents on the day prior to the interview (Table 3).

\section{Discussion}

Market foods, although largely unavailable to Inuit during the first half of the 20th century, now constitute over $80 \%$ of the total diet (based on energy). As recently as 1987, country foods provided nearly half (46.5\% TDE) of the total diet of Inuit men (based on September data from the Qikiqtaaluk region) ${ }^{(40)}$. By contrast, the highest contribution of country foods reported in the present study was just over a quarter (27.6\%) of TDE, based on older Inuit men in Nunavut. The attenuation of country food consumption has come at the expense of diet quality and nutrient adequacy, and bears important implications for the risk of obesity and chronic disease ${ }^{(5)}$. Consumption of sweets (including sweetened beverages, sugar added to coffee/tea, pastries, other desserts) and potato chips was reported by over $90 \%$ of participants in the present study, while less than a quarter of participants reported consumption of solid fruits. Collectively, sweets and potato chips represented approximately a quarter of TDE (23$27 \%$ ), nearly half of total carbohydrates (42-50\%) and the vast majority of total sugar (65-79\%), while contributing less than $5-10 \%$ of most vitamins and minerals. Notwithstanding this change, our results continue to show that country foods, despite their modest contribution to TDE, contribute substantively to the intakes of protein and many micronutrients, including Fe, vitamins $\mathrm{D}, \mathrm{B}_{6}$ and $\mathrm{B}_{12}$, and niacin ${ }^{(17,41-45)}$. These findings echo long-held local knowledge that country foods contribute importantly to nutritional well-being in Inuit communities ${ }^{(46)}$.

Previous research has identified dietary fibre, Ca, folate and vitamins $\mathrm{A}, \mathrm{D}$ and $\mathrm{E}$ (and to a lesser extent, vitamin C) as nutrients of issue (i.e. consumed inadequately and/or low intakes) in the contemporary diet of Inuit in Canada $^{(5,9,10,17,18,44,47,48)}$. Nutrients of issue, namely dietary fibre and $\mathrm{Ca}$, tend to be those for which country foods 
Table 3 Mean* $^{*}$ consumption (g/person per d) of market foods by adult Inuit respondents of the $24 \mathrm{~h}$ recall $(n$ 2095), by region; Inuit Health Survey, 2007-2008

\begin{tabular}{|c|c|c|c|c|c|c|c|c|c|}
\hline \multirow[b]{2}{*}{ Market food groups/subgroups $†$} & \multicolumn{3}{|c|}{ Nunavut ( $n$ 1568) } & \multicolumn{3}{|c|}{ Inuvialuit Settlement Region ( $n$ 267) } & \multicolumn{3}{|c|}{ Nunatsiavut ( $n$ 260) } \\
\hline & $\%$ of recalls & Mean & SD & $\%$ of recalls & Mean & SD & $\%$ of recalls & Mean & SD \\
\hline Dairy products & $62 \cdot 0$ & $48 \cdot 5$ & 132 & $69 \cdot 3$ & $65 \cdot 0$ & 128 & $72 \cdot 3$ & 93.5 & 185 \\
\hline Milk & $17 \cdot 6$ & $32 \cdot 7$ & 120 & $25 \cdot 1$ & 41.5 & 12 & $60 \cdot 0$ & $81 \cdot 8$ & 82 \\
\hline Coffee whitener and milk powder & $40 \cdot 4$ & $5 \cdot 3$ & 16 & $34 \cdot 1$ & 3.4 & 9 & $6 \cdot 9$ & 1.0 & 6 \\
\hline Cream & $5 \cdot 7$ & 1.8 & 11 & 10.5 & 4.9 & 21 & 1.9 & 0.9 & 9 \\
\hline Cheese & 13.5 & 5.7 & 21 & $21 \cdot 0$ & $8 \cdot 6$ & 25 & 23.5 & 7.5 & 19 \\
\hline Yoghurt & 1.4 & $2 \cdot 7$ & 42 & $5 \cdot 6$ & $6 \cdot 6$ & 30 & 1.9 & $2 \cdot 2$ & 19 \\
\hline Added fat & 51.7 & $10 \cdot 4$ & 22 & 68.5 & 14.7 & 21 & $72 \cdot 7$ & 11.4 & 14 \\
\hline Table fat & 33.5 & 3.7 & 9 & $56 \cdot 2$ & $7 \cdot 2$ & 12 & 63.5 & $7 \cdot 0$ & 10 \\
\hline Vegetable oil & $10 \cdot 3$ & 1.8 & 9 & 14.2 & 2.4 & 8 & $16 \cdot 5$ & $2 \cdot 0$ & 7 \\
\hline Lard and shortening & $13 \cdot 8$ & 3.5 & 15 & $10 \cdot 9$ & $2 \cdot 4$ & 9 & $2 \cdot 7$ & 0.5 & 4 \\
\hline Salad dressing and mayonnaise & $7 \cdot 0$ & 1.4 & 9 & $16 \cdot 1$ & $2 \cdot 7$ & 9 & $12 \cdot 7$ & 1.9 & 6 \\
\hline Market meat and alternatives & $67 \cdot 6$ & 144.3 & 180 & $87 \cdot 3$ & 228.8 & 220 & $90 \cdot 0$ & 247.8 & 225 \\
\hline Poultry & 18.9 & 36.8 & 97 & $25 \cdot 8$ & 47.5 & 109 & 34.6 & 53.1 & 97 \\
\hline Pork & $18 \cdot 8$ & $17 \cdot 3$ & 76 & $22 \cdot 8$ & $21 \cdot 7$ & 62 & $27 \cdot 3$ & $24 \cdot 0$ & 59 \\
\hline Beef & $17 \cdot 1$ & $23 \cdot 4$ & 72 & $23 \cdot 2$ & $27 \cdot 4$ & 66 & $26 \cdot 5$ & $32 \cdot 3$ & 87 \\
\hline Processed meat & $16 \cdot 4$ & 14.2 & 45 & $20 \cdot 2$ & $17 \cdot 0$ & 54 & $25 \cdot 0$ & $23 \cdot 6$ & 55 \\
\hline Eggs & $22 \cdot 1$ & 23.9 & 52 & 24.7 & $28 \cdot 8$ & 67 & $26 \cdot 5$ & $25 \cdot 2$ & 54 \\
\hline Fish and shellfish & 4.7 & $6 \cdot 7$ & 43 & $19 \cdot 9$ & 23.9 & 72 & 18.5 & $32 . \overline{7}$ & 105 \\
\hline Broth and gravy & $10 \cdot 9$ & 20.5 & 78 & $20 \cdot 2$ & $59 \cdot 6$ & 160 & $27 \cdot 3$ & 55.5 & 134 \\
\hline Alternatives & 4.7 & $1 \cdot 2$ & 9 & 7.5 & $2 \cdot 7$ & 15 & $8 \cdot 8$ & $1 \cdot 3$ & 7 \\
\hline Fruits and fruit juice & $25 \cdot 1$ & $99 \cdot 0$ & 261 & 38.2 & 131.5 & 282 & $46 \cdot 2$ & 185.5 & 363 \\
\hline Fruit (solid) & $13 \cdot 4$ & $23 \cdot 2$ & 80 & 24.7 & $43 \cdot 1$ & 124 & $16 \cdot 9$ & $25 \cdot 9$ & 71 \\
\hline Fruit (juice) & $12 \cdot 7$ & $70 \cdot 1$ & 236 & $15 \cdot 0$ & $72 \cdot 8$ & 230 & $31 \cdot 2$ & 145.4 & 329 \\
\hline Canned fruit & 3.0 & 5.5 & 37 & $5 \cdot 6$ & $15 \cdot 4$ & 83 & 4.2 & $13 \cdot 2$ & 98 \\
\hline Dried fruit & 1.3 & 0.3 & 5 & 2.6 & 0.2 & 2 & 4.2 & 1.0 & 8 \\
\hline Vegetables & 43.3 & 68.5 & 138 & 61.4 & $115 \cdot 2$ & 189 & $62 \cdot 7$ & $95 \cdot 1$ & 151 \\
\hline Solid vegetable & 38.0 & 41.7 & 91 & $52 \cdot 8$ & $63 \cdot 1$ & 110 & 58.8 & $66 \cdot 7$ & 107 \\
\hline Vegetable sauce and soup & $10 \cdot 7$ & $26 \cdot 8$ & 102 & 18.7 & $52 \cdot 2$ & 150 & 11.5 & 28.4 & 107 \\
\hline Cereals, grains and starches & 87.6 & $186 \cdot 0$ & 191 & $92 \cdot 9$ & 247.0 & 202 & $97 \cdot 7$ & $216 \cdot 5$ & 166 \\
\hline Bread & 49.8 & 37.7 & 61 & 68.9 & 67.8 & 80 & $80 \cdot 0$ & 65.1 & 61 \\
\hline Bannock & $24 \cdot 3$ & 31.1 & 83 & 14.6 & $15 \cdot 2$ & 49 & $2 \cdot 7$ & $3 \cdot 1$ & 25 \\
\hline Crackers and other & 21.5 & $10 \cdot 0$ & 31 & $24 \cdot 3$ & $13 \cdot 1$ & 47 & 28.5 & $11 \cdot 3$ & 26 \\
\hline Pasta & 10.5 & $25 \cdot 2$ & 92 & 19.5 & $25 \cdot 0$ & 79 & 11.5 & $26 \cdot 8$ & 115 \\
\hline Rice & $20 \cdot 7$ & $35 \cdot 3$ & 93 & $30 \cdot 0$ & $38 \cdot 2$ & 85 & $25 \cdot 0$ & $30 \cdot 0$ & 75 \\
\hline Cereals & $12 \cdot 9$ & 11.9 & 49 & $21 \cdot 7$ & 44.0 & 119 & $17 \cdot 7$ & $17 \cdot 4$ & 59 \\
\hline Potatoes & 31.4 & 34.6 & 82 & $37 \cdot 1$ & 43.2 & 81 & $56 \cdot 5$ & $62 \cdot 7$ & 89 \\
\hline Sweets and snacks & $93 \cdot 1$ & 653.7 & 821 & $92 \cdot 1$ & $616 \cdot 4$ & 746 & 94.6 & 465.9 & 644 \\
\hline Sweetened beverages & 64.2 & 577.8 & 795 & $57 \cdot 7$ & 533.0 & 724 & 44.2 & 369.8 & 601 \\
\hline Sugar & 69.8 & $36 \cdot 4$ & 61 & 65.5 & $17 \cdot 7$ & 27 & $71 \cdot 2$ & $21 \cdot 7$ & 35 \\
\hline Sweet toppings and spreads & $10 \cdot 3$ & $2 \cdot 1$ & 14 & $15 \cdot 7$ & 4.5 & 20 & $24 . \overline{6}$ & $5 \cdot 2$ & 13 \\
\hline Chocolate and candy & 14.9 & $10 \cdot 5$ & 40 & $16 \cdot 9$ & $17 \cdot 3$ & 66 & 20.4 & $13 \cdot 1$ & 49 \\
\hline Pastries & $15 \cdot 1$ & 10.9 & 37 & $18 \cdot 4$ & $22 \cdot 4$ & 85 & $24 \cdot 6$ & $18 \cdot 2$ & 47 \\
\hline Sweet dairy products & 3.4 & 3.6 & 28 & $6 \cdot 7$ & $10 \cdot 3$ & 49 & $7 \cdot 3$ & $9 \cdot 8$ & 44 \\
\hline Potato chips & $19 \cdot 3$ & $12 \cdot 4$ & 38 & 13.9 & $11 \cdot 3$ & 38 & $27 \cdot 7$ & $28 \cdot 1$ & 72 \\
\hline Mixed dishes and other & 51.0 & 134.7 & 221 & $55 \cdot 1$ & 153.2 & 245 & $50 \cdot 4$ & 105.4 & 201 \\
\hline Mixtures (grain) & $32 \cdot 4$ & 91.0 & 187 & 37.8 & 109.9 & 217 & $26 \cdot 9$ & $58 \cdot 2$ & 146 \\
\hline Mixtures (meat) & $14 \cdot 1$ & 38.5 & 123 & $10 \cdot 1$ & 23.5 & 92 & 11.9 & 40.4 & 147 \\
\hline Sauces and condiments & $16 \cdot 0$ & 4.9 & 21 & 21.0 & $10 \cdot 0$ & 33 & 21.5 & $6 \cdot 9$ & 22 \\
\hline Low-calorie items & 92.9 & $1377 \cdot 4$ & 1282 & 94.4 & 1491.6 & 1118 & $96 \cdot 5$ & $1267 \cdot 9$ & 1168 \\
\hline Coffee and tea & $87 \cdot 1$ & $1100 \cdot 7$ & 1121 & $87 \cdot 3$ & $976 \cdot 1$ & 903 & 85.4 & $706 \cdot 8$ & 684 \\
\hline Diet/low-calorie beverages & $6 \cdot 0$ & 33.8 & 162 & 3.7 & 29.7 & 198 & $20 \cdot 0$ & $117 \cdot 4$ & 285 \\
\hline Salt and seasoning & $11 \cdot 1$ & 0.3 & 1 & 19.5 & 0.4 & 2 & $13 \cdot 1$ & 0.3 & 2 \\
\hline
\end{tabular}

*Population mean (consumers and non-consumers), by region.

†The detailed categorization scheme for market foods is presented in the online supplementary material, Supplemental Table 2.

are not generally considered a major contributor $(<5 \%$ of total intake). However, $\mathrm{Ca}$ and fibre are understudied in several country foods such as skins/muktuk (fibre) and broths (Ca). Sweetened beverages were the principal source of both Ca (up to $17 \%$ ) and vitamin C (up to $46 \%$ ) among Inuit in Nunavut and the ISR. Alternative sources of $\mathrm{Ca}$ and vitamin $\mathrm{C}$ should be identified, as sweetened beverages were the main source of total sugar across all regions (31-44\%) and consumption of high-sugar beverages in this population has been associated with an atrisk $\mathrm{BMI}^{(49)}$. Furthermore, nutrient intakes from fortified foods may be overestimated if the fortificant is prone to uneven dispersion in the food (e.g. settling of Ca to the bottom of carton in Ca-fortified beverages ${ }^{(50)}$ ). Roughly half of the total $\mathrm{Ca}$ intake in the diet of Canadian adults is derived from milk and cheese ${ }^{(51)}$. By contrast, these foods 
Table 4 Percentage contribution to macronutrient and dietary fibre intakes from the top ten dietary sources among Inuit adults ( $n$ 2095), by region; Inuit Health Survey, 2007-2008

\begin{tabular}{|c|c|c|c|c|c|c|c|c|c|c|c|c|c|c|}
\hline & \multicolumn{2}{|l|}{ Energy } & \multicolumn{2}{|l|}{ Protein } & \multicolumn{2}{|c|}{ Carbohydrates } & \multicolumn{2}{|l|}{ Fat } & \multicolumn{2}{|l|}{ Saturated fat } & \multicolumn{2}{|l|}{ PUFA } & \multicolumn{2}{|l|}{ Dietary fibre } \\
\hline & Source & $\%$ & Source & $\%$ & Source & $\%$ & Source & $\%$ & Source & $\%$ & Source & $\%$ & Source & $\%$ \\
\hline \multirow[t]{11}{*}{$\begin{array}{l}\text { Nunavut } \\
\qquad(n 1568)\end{array}$} & Total (kJ/kcal) & $\begin{array}{l}8694 / \\
2078\end{array}$ & Total (g) & 109 & Total (g) & 240 & Total (g) & 76 & Total (g) & 24 & Total (g) & 13 & Total (g) & 9 \\
\hline & $\begin{array}{l}\text { Sweetened } \\
\text { beverages }\end{array}$ & $11 \cdot 3$ & Caribou* ${ }^{*}$ & $27 \cdot 2$ & $\begin{array}{l}\text { Sweetened } \\
\text { beverages }\end{array}$ & $25 \cdot 2$ & Caribou* & $8 \cdot 3$ & Caribou* ${ }^{*}$ & $11 \cdot 6$ & Potato chips & $10 \cdot 3$ & Bread & 13.7 \\
\hline & Caribou $^{*}$ & $8 \cdot 8$ & Fish $^{*}$ & 9.7 & Sugar & $15 \cdot 2$ & Poultry & $6 \cdot 6$ & $\begin{array}{l}\text { Coffee whitener and milk } \\
\text { powder }\end{array}$ & $7 \cdot 1$ & Poultry & $9 \cdot 7$ & Vegetables (solid) & 11.2 \\
\hline & Sugar & 6.8 & Poultry & 7.9 & Bread & 7.8 & Beluga whale ${ }^{*}$ & $6 \cdot 3$ & Mixtures (grain) & 6.9 & Caribou* $^{*}$ & 7.6 & Mixtures (grain) & $\begin{array}{l}9.9 \\
7.7\end{array}$ \\
\hline & Mixtures (grain) & $6 \cdot 1$ & Beluga whale* & 6.5 & Pasta and Rice & $7 \cdot 2$ & Mixtures (grain) & $6 \cdot 3$ & Table fat & 6.5 & Mixtures (grain) & $6 \cdot 2$ & Potatoes & $\begin{array}{r}7.7 \\
6.6\end{array}$ \\
\hline & Bread & $5 \cdot 1$ & Beef & $6 \cdot 2$ & Mixtures (grain) & 6.5 & Potato chips & 5.4 & Beef & $6 \cdot 3$ & Crackers and other & 5.5 & Pasta and Rice & 6.6 \\
\hline & Poultry & $4 \cdot 3$ & Mixtures (grain) & 4.8 & Bannock & 4.5 & Beef & 5.0 & Lard and shortening & 5.4 & Bread & $5 \cdot 2$ & Cereals & $6 \cdot 6$ \\
\hline & Pasta and Rice & $4 \cdot 1$ & Seal and walrus* ${ }^{*}$ & 4.6 & $\begin{array}{l}\text { Chocolate and } \\
\text { candy }\end{array}$ & $3 \cdot 2$ & $\begin{array}{l}\text { Processed } \\
\text { meat }\end{array}$ & 4.6 & Poultry & $5 \cdot 1$ & Fish $^{*}$ & 4.5 & Mixtures (meat) & $5 \cdot 8$ \\
\hline & Bannock & 3.8 & Pork & 4.3 & Potatoes & $3 \cdot 2$ & $\begin{array}{l}\text { Lard and } \\
\text { shortening }\end{array}$ & 4.5 & Pork & 4.7 & Eggs & $4 \cdot 1$ & Fruit (solid) & $5 \cdot 7$ \\
\hline & Beluga whale* & 3.7 & Bread & $3 \cdot 2$ & Fruit (juice) & $3 \cdot 1$ & Pork & 4.3 & Bannock & 4.6 & Vegetable oil & 3.9 & Potato chips & 4.9 \\
\hline & Fish $^{*}$ & 3.3 & Mixtures (meat) & $2 \cdot 8$ & Cereals & $2 \cdot 8$ & Bannock & $4 \cdot 2$ & Processed meat & $4 \cdot 3$ & Bannock & 3.7 & Bannock & 4.8 \\
\hline \multirow{11}{*}{$\begin{array}{l}\text { Inuvialuit Settlement } \\
\text { Region } \\
(n \text { 267) }\end{array}$} & Total (kJ/kcal) & $\begin{array}{l}9711 / \\
2321\end{array}$ & Total (g) & 118 & Total (g) & 260 & Total (g) & 90 & Total (g) & 28 & Total (g) & 18 & Total (g) & 12 \\
\hline & $\begin{array}{l}\text { Sweetened } \\
\text { beverages }\end{array}$ & $9 \cdot 3$ & Caribou* & $18 \cdot 7$ & $\begin{array}{l}\text { Sweetened } \\
\text { beverages }\end{array}$ & $21 \cdot 4$ & Poultry & $6 \cdot 6$ & Table fat & 8.5 & Poultry & $8 \cdot 3$ & Bread & 19.6 \\
\hline & Bread & 8.4 & Fish $^{*}$ & 14.9 & Bread & $12 \cdot 9$ & Mixtures (grain) & 6.5 & Caribou $^{*}$ & $7 \cdot 7$ & Bread & $7 \cdot 7$ & Cereals & $10 \cdot 2$ \\
\hline & Mixtures (grain) & $6 \cdot 7$ & Poultry & 9.5 & Mixtures (grain) & $7 \cdot 7$ & Table fat & $6 \cdot 4$ & Mixtures (grain) & $7 \cdot 1$ & Fish $^{\star}$ & 6.6 & Vegetable (solid) & $\begin{array}{r}10.0 \\
9.0\end{array}$ \\
\hline & Caribou* $^{*}$ & 5.6 & Beef & 6.7 & Pasta and Rice & 7.1 & Fish $^{*}$ & 5.5 & Chocolate and candy & 5.7 & Potato chips & $6 \cdot 6$ & Mixtures (grain) & 9.0 \\
\hline & Fish $^{*}$ & $5 \cdot 3$ & Pork & $5 \cdot 1$ & Sugar & 6.8 & Beluga whale* & 5.1 & Beef & 5.7 & Mixtures (grain) & $6 \cdot 3$ & Fruit (solid) & 6.9 \\
\hline & Poultry & 4.8 & Bread & $5 \cdot 0$ & $\begin{array}{l}\text { Chocolate and } \\
\text { candy }\end{array}$ & 4.8 & Pastries & 4.8 & Pastries & $5 \cdot 7$ & Crackers and other & $5 \cdot 1$ & Potatoes & 6.8 \\
\hline & Pasta and Rice & 4.0 & Mixtures (grain) & 4.6 & Pastries & 4.3 & Beef & 4.6 & Cheese & $5 \cdot 2$ & Table fat & 4.8 & Pasta and Rice & 5.4 \\
\hline & Pastries & 3.7 & Beluga whale* & 4.5 & Cereals & 4.3 & Pork & $4 \cdot 3$ & Pork & 5.0 & $\begin{array}{l}\text { Salad dressing \& } \\
\text { mayonnaise }\end{array}$ & 4.8 & Crackers and other & $5 \cdot 0$ \\
\hline & $\begin{array}{l}\text { Chocolate and } \\
\text { candy }\end{array}$ & $3 \cdot 4$ & Fish and shellfish & 4.4 & Potatoes & 3.6 & Caribou* $^{*}$ & $4 \cdot 3$ & Poultry & 4.9 & Pastries & 4.7 & Pastries & 3.2 \\
\hline & Beef & $3 \cdot 2$ & Birds* & 3.0 & $\begin{array}{l}\text { Crackers and } \\
\text { other }\end{array}$ & $3 \cdot 2$ & Potato chips & 4.1 & Eggs & 3.7 & Other mixed dishes & 4.4 & Potato chips & 3.1 \\
\hline \multirow[t]{10}{*}{$\begin{array}{l}\text { Nunatsiavut } \\
\quad(n 260)\end{array}$} & Total (kJ/kcal) & $\begin{array}{l}8284 / \\
1980\end{array}$ & Total (g) & 94 & Total (g) & 238 & Total (g) & 74 & Total (g) & 23 & Total (g) & 15 & Total (g) & 12 \\
\hline & Bread & $9 \cdot 3$ & Poultry & $13 \cdot 6$ & $\begin{array}{l}\text { Sweetened } \\
\text { beverages }\end{array}$ & $15 \cdot 7$ & Potato chips & $12 \cdot 5$ & Table fat & 8.8 & Potato chips & 19.4 & Bread & 17.7 \\
\hline & Potato chips & 7.4 & Caribou $^{*}$ & $13 \cdot 0$ & Bread & 13.9 & Poultry & 8.2 & Processed meat & 7.5 & Poultry & $9 \cdot 7$ & Vegetables (solid) & 12.5 \\
\hline & $\begin{array}{l}\text { Sweetened } \\
\text { beverages }\end{array}$ & $7 \cdot 3$ & Beef & 8.8 & Sugar & 9.1 & Table fat & 7.5 & Beef & $7 \cdot 3$ & Bread & $8 \cdot 2$ & Potatoes & $9 \cdot 4$ \\
\hline & Poultry & $5 \cdot 8$ & Fish and shellfish & 8.0 & Pasta and Rice & 6.8 & $\begin{array}{l}\text { Processed } \\
\text { meat }\end{array}$ & $7 \cdot 1$ & Milk & $7 \cdot 2$ & Table fat & $6 \cdot 6$ & Mixtures (meat) & 8.6 \\
\hline & Mixtures (grain) & 4.4 & Pork & $7 \cdot 0$ & Fruit (juice) & 6.5 & Beef & $5 \cdot 9$ & Poultry & $7 \cdot 0$ & Crackers and other & $5 \cdot 8$ & Potato chips & $\begin{array}{l}8.4 \\
7.6\end{array}$ \\
\hline & Sugar & 4.2 & Bread & 6.4 & Potato chips & 6.4 & Pork & $5 \cdot 7$ & Pork & 6.5 & Pastries & 4.8 & Cereals & $\begin{array}{l}7.6 \\
5.5\end{array}$ \\
\hline & Pasta and Rice & 4.1 & Fish $^{*}$ & 5.7 & Potatoes & 5.6 & Mixtures (grain) & 4.8 & Cheese & $5 \cdot 3$ & Mixtures (grain) & 4.5 & Pasta and Rice & 5.5 \\
\hline & Beef & 3.9 & Milk & 3.9 & Pastries & 4.4 & Pastries & 4.4 & Mixtures (grain) & $5 \cdot 3$ & Fish and shellfish & 4.2 & Mixtures (grain) & $\begin{array}{l}5.5 \\
4.7\end{array}$ \\
\hline & Pastries & 3.7 & Processed meat & 3.8 & Mixtures (grain) & 4.3 & Eggs & 4.1 & Potato chips & $5 \cdot 2$ & Pork & 3.9 & Fruit (solid) & 4.7 \\
\hline
\end{tabular}

${ }^{*}$ Country food items. 
Table 5 Percentage contribution to vitamin intakes from the top ten dietary sources among Inuit adults ( $n$ 2095), by region; Inuit Health Survey, 2007-2008

\begin{tabular}{|c|c|c|c|c|c|c|c|c|c|c|c|c|c|c|}
\hline & \multicolumn{2}{|l|}{ Vitamin A } & \multicolumn{2}{|l|}{ Vitamin C } & \multicolumn{2}{|l|}{ Vitamin D } & \multicolumn{2}{|l|}{ Vitamin E† } & \multicolumn{2}{|l|}{ Thiamin } & \multicolumn{2}{|l|}{ Riboflavin } & \multicolumn{2}{|l|}{ Vitamin $B_{12}$} \\
\hline & Source & $\%$ & Source & $\%$ & Source & $\%$ & Source & $\%$ & Source & $\%$ & Source & $\%$ & Source & $\%$ \\
\hline \multirow{11}{*}{$\begin{array}{l}\text { Nunavut } \\
\quad(n \text { 1568) }\end{array}$} & Total ( $\mu \mathrm{g}$ RAE) & 664 & Total (mg) & 125 & Total $(\mathrm{mg})$ & 8 & Total (mg) & 7 & Total (mg) & 2 & Total (mg) & 3 & Total (mg) & 14 \\
\hline & Beluga whale* & 31.2 & Sweetened beverages & 44.5 & Fish $^{*}$ & $60 \cdot 7$ & Potato chips & 13.9 & Caribou** & $13 \cdot 1$ & Caribou* ${ }^{*}$ & $32 \cdot 1$ & Caribou* & 44.0 \\
\hline & Vegetables (solid) & 13.4 & Fruit (juice) & 18.9 & Beluga whale* & 6.9 & Mixtures (grain) & 9.8 & Narwhal ${ }^{*}$ & 10.9 & Coffee and tea & $20 \cdot 1$ & Fish $^{*}$ & $22 \cdot 7$ \\
\hline & Narwhal ${ }^{*}$ & $10 \cdot 0$ & Beluga whale* & $6 \cdot 8$ & Eggs & 5.4 & Eggs & 9.3 & Cereals & 8.5 & Fish $^{*}$ & $5 \cdot 2$ & Beluga whale* & $6 \cdot 2$ \\
\hline & Caribou $^{*}$ & 7.8 & Berries* & 4.5 & Milk & 4.5 & Beluga whale* & 8.6 & Bread & 7.9 & Mixtures (grain) & 4.7 & Seal and walrus* & 5.4 \\
\hline & Eggs & 7.8 & Fruit (solid) & 3.9 & Mixtures (grain) & 3.0 & Caribou* $^{*}$ & 6.3 & Mixtures (grain) & 7.7 & Bread & 4.6 & Beef & 3.8 \\
\hline & Table fat & 4.0 & Vegetables (solid) & 3.7 & Narwhal $^{\star}$ & 2.5 & Narwhal $^{*}$ & 4.4 & Fish $^{*}$ & 7.6 & Eggs & 4.0 & Fish and shellfish & 2.7 \\
\hline & Fish $^{*}$ & 3.4 & Potato chips & 3.5 & Pork & $2 \cdot 4$ & Vegetable oil & 4.4 & Bannock & 5.7 & Bannock & 2.5 & Eggs & 2.7 \\
\hline & Milk & $3 \cdot 2$ & Narwhal ${ }^{*}$ & 2.5 & Bread & 1.9 & $\begin{array}{l}\text { Crackers and } \\
\text { other }\end{array}$ & 4.0 & Pasta and Rice & $5 \cdot 3$ & Poultry & $2 \cdot 3$ & Narwhal ${ }^{*}$ & $2 \cdot 4$ \\
\hline & Mixtures (grain) & 3.2 & Potatoes & 2.4 & Cereals & 1.7 & Fish $^{*}$ & 3.5 & Pork & 4.8 & Milk & $2 \cdot 3$ & Mixtures (grain) & 1.7 \\
\hline & Mixtures (meat) & $2 \cdot 8$ & Caribou* $^{*}$ & 1.8 & Caribou* $^{*}$ & 1.5 & Poultry & 3.5 & Coffee and tea & 4.1 & $\begin{array}{l}\text { Seal and } \\
\text { walrus* }\end{array}$ & $2 \cdot 2$ & Mixtures (meat) & 1.5 \\
\hline \multirow{11}{*}{$\begin{array}{l}\text { Inuvialuit Settlement Region } \\
\text { (n 267) }\end{array}$} & Total ( $\mu \mathrm{g}$ RAE) & 680 & Total (mg) & 143 & Total (mg) & 13 & Total (g) & 9 & Total (mg) & 2 & Total (mg) & 3 & Total (mg) & 13 \\
\hline & Beluga whale ${ }^{\star}$ & 24.7 & Sweetened beverages & $46 \cdot 2$ & Fish $^{\star}$ & 65.9 & Mixtures (grain) & 10.5 & Bread & 13.4 & Caribou $^{*}$ & 21.0 & Caribou* & 33.8 \\
\hline & Vegetables (solid) & $14 \cdot 3$ & Fruit (juice) & 18.4 & $\begin{array}{l}\text { Fish and } \\
\text { shellfish }\end{array}$ & 7.1 & Potato chips & $10 \cdot 3$ & Cereals & 10.9 & Coffee and tea & 20.7 & Fish $^{*}$ & $28 \cdot 3$ \\
\hline & Eggs & $9 \cdot 0$ & Vegetables (solid) & 6.9 & Beluga whale* & 4.9 & Eggs & 7.9 & Fish $^{*}$ & $10 \cdot 0$ & Fish* $^{*}$ & $8 \cdot 1$ & Fish and shellfish & 7.2 \\
\hline & $\begin{array}{l}\text { Other land } \\
\text { mammals* }\end{array}$ & 8.0 & Fruit (solid) & 6.6 & Eggs & 4.0 & Beluga whale* & 6.5 & Mixtures (grain) & 9.7 & Bread & $7 \cdot 1$ & $\begin{array}{l}\text { Other land } \\
\text { mammals* }\end{array}$ & 5.9 \\
\hline & Table fat & 7.9 & Beluga whale* & 4.4 & Milk & 3.6 & Fish $^{*}$ & 6.1 & Caribou* & 8.6 & Mixtures (grain) & 5.4 & Beluga whale* & 4.8 \\
\hline & Fish $^{*}$ & 5.0 & Potatoes & 2.8 & Mixtures (grain) & 2.8 & Bread & 5.7 & Pork & 6.3 & Eggs & 4.6 & Beef & 4.6 \\
\hline & Milk & $4 \cdot 1$ & Potato chips & 2.5 & Bread & 1.9 & $\begin{array}{l}\text { Crackers and } \\
\text { other }\end{array}$ & 4.5 & Pasta and Rice & 5.6 & Milk & 2.9 & Eggs & 3.3 \\
\hline & Mixtures (grain) & 3.7 & Fish $^{\star}$ & $2 \cdot 2$ & Birds $^{*}$ & 1.7 & Vegetable oil & 4.4 & Coffee and tea & 4.5 & Poultry & 2.8 & Milk & 1.5 \\
\hline & Cheese & $2 \cdot 9$ & Berries* & $2 \cdot 0$ & Pork & 1.2 & Fish and shellfish & 4.2 & Bannock & 2.9 & Pork & 2.5 & Pork & 1.4 \\
\hline & Bread & $2 \cdot 1$ & Milk & 1.3 & $\begin{array}{l}\text { Processed } \\
\text { meat }\end{array}$ & 1.0 & Pastries & 4.0 & $\begin{array}{l}\text { Processed } \\
\text { meat }\end{array}$ & 2.8 & Beef & 2.4 & Poultry & 1.4 \\
\hline \multirow{11}{*}{$\begin{array}{l}\text { Nunatsiavut } \\
\quad(n 260)\end{array}$} & Total ( $\mu \mathrm{g}$ RAE) & 491 & Total (mg) & 118 & Total (mg) & 6 & Total $(\mathrm{g})$ & 8 & Total $(\mathrm{mg})$ & 2 & Total (mg) & 2 & Total (mg) & 9 \\
\hline & Vegetables (solid) & 27.3 & Fruit (juice) & 44.5 & Fish $^{\star}$ & 34.6 & Potato chips & 29.8 & Bread & 17.7 & Caribou $^{*}$ & 15.4 & Caribou $^{*}$ & 26.6 \\
\hline & Milk & 11.4 & Sweetened beverages & $17 \cdot 2$ & $\begin{array}{l}\text { Fish and } \\
\text { shellfish }\end{array}$ & $16 \cdot 8$ & Eggs & 8.6 & Cereals & 9.0 & Bread & 10.8 & Fish $^{*}$ & 18.7 \\
\hline & Eggs & 11.0 & Vegetables (solid) & 8.8 & Milk & $16 \cdot 3$ & Mixtures (grain) & 6.3 & Pork & 8.9 & Coffee and tea & 10.6 & Fish and shellfish & $16 \cdot 2$ \\
\hline & Table fat & $10 \cdot 8$ & Potato chips & 7.8 & Eggs & 7.0 & Fish and shellfish & $5 \cdot 2$ & Pasta and Rice & 6.1 & & 8.9 & Beef & 10.5 \\
\hline & $\begin{array}{l}\text { Other land } \\
\text { mammals* }\end{array}$ & 4.5 & Milk & $6 \cdot 6$ & Bread & 3.6 & Bread & 4.8 & Caribou $^{*}$ & 5.8 & Eggs & 5.5 & Eggs & 4.4 \\
\hline & Beef & 4.4 & Potatoes & $5 \cdot 0$ & Pork & 3.2 & Vegetable oil & 4.5 & Mixtures (grain) & 5.6 & Poultry & $5 \cdot 1$ & Milk & 3.7 \\
\hline & Cheese & 3.7 & Fruit (solid) & 3.9 & Birds ${ }^{*}$ & 3.1 & $\begin{array}{l}\text { Crackers and } \\
\text { other }\end{array}$ & 3.9 & $\begin{array}{l}\text { Processed } \\
\text { meat }\end{array}$ & 5.4 & Beef & 4.2 & Poultry & 3.6 \\
\hline & Fish $^{*}$ & $3 \cdot 3$ & Caribou ${ }^{*}$ & 0.9 & $\begin{array}{l}\text { Processed } \\
\text { meat }\end{array}$ & 3.0 & Pastries & 3.7 & Fish* & 4.5 & Mixtures (grain) & 4.0 & Processed meat & 2.9 \\
\hline & Mixtures (grain) & $2 \cdot 6$ & Mixtures (meat) & 0.9 & Cheese & $2 \cdot 0$ & $\begin{array}{l}\text { Vegetables } \\
\text { (solid) }\end{array}$ & 3.5 & Potato chips & 4.1 & Fish $^{*}$ & 3.8 & $\begin{array}{l}\text { Other land } \\
\text { mammals }\end{array}$ & 2.4 \\
\hline & Mixtures (meat) & $2 \cdot 3$ & $\begin{array}{l}\text { Vegetables (sauce and } \\
\text { soup) }\end{array}$ & 0.9 & Mixtures (grain) & 1.5 & Table fat & 3.4 & $\begin{array}{l}\text { Fish and } \\
\text { shellfish }\end{array}$ & 3.93 & Pork & 3.6 & Pork & $2 \cdot 2$ \\
\hline
\end{tabular}


Table 6 Percentage contribution to mineral intakes from the top ten dietary sources among Inuit adults ( $n$ 2095), by region; Inuit Health Survey, 2007-2008

\begin{tabular}{|c|c|c|c|c|c|c|c|c|c|c|c|c|c|c|}
\hline & \multicolumn{2}{|l|}{$\mathrm{Ca}$} & \multicolumn{2}{|l|}{$\mathrm{Fe}$} & \multicolumn{2}{|l|}{$\mathrm{Mg}$} & \multicolumn{2}{|l|}{$\mathrm{Zn}$} & \multicolumn{2}{|l|}{$\mathrm{Cu}$} & \multicolumn{2}{|l|}{ Se } & \multicolumn{2}{|l|}{$\mathrm{Na}$} \\
\hline & Source & $\%$ & Source & $\%$ & Source & $\%$ & Source & $\%$ & Source & $\%$ & Source & $\%$ & Source & $\%$ \\
\hline \multirow{11}{*}{$\begin{array}{l}\text { Nunavu } \\
\qquad(n 1568)\end{array}$} & Total (mg) & 493 & Total (mg) & 21 & Total (mg) & 233 & Total (mg) & 16 & Total (mg) & 1 & Total (mg) & 269 & Total (mg) & 2386 \\
\hline & $\begin{array}{l}\text { Sweetened } \\
\text { beverages }\end{array}$ & $17 \cdot 1$ & Caribou $^{*}$ & $26 \cdot 6$ & Coffee and tea & $14 \cdot 1$ & Caribou $^{*}$ & 31.3 & Caribou* $^{*}$ & 29.2 & Beluga whale* & $26 \cdot 0$ & Mixtures (grain) & 14.9 \\
\hline & Bannock & 11.8 & Seal and walrus* & $20 \cdot 1$ & Caribou $^{*}$ & $13 \cdot 1$ & Beluga whale* & 11.5 & Mixtures (grain) & 6.7 & Mixtures (grain) & 23.5 & Bread & 8.3 \\
\hline & Mixtures (grain) & 11.6 & Bread & 6.0 & Mixtures (grain) & $6 \cdot 3$ & Beef & $9 \cdot 3$ & Bread & 4.7 & Narwhal $^{*}$ & 14.9 & Mixtures (meat) & $7 \cdot 4$ \\
\hline & Milk & 9.0 & Mixtures (grain) & $5 \cdot 2$ & Bread & $6 \cdot 1$ & Narwhal ${ }^{*}$ & 4.7 & Potatoes & 3.8 & Bread & 4.0 & Processed meat & 6.8 \\
\hline & Bread & 7.3 & Cereals & 4.7 & Fish $^{*}$ & $5 \cdot 8$ & Mixtures (grain) & 3.9 & Fish $^{*}$ & 3.8 & Caribou* & 3.7 & Bannock & $5 \cdot 1$ \\
\hline & Cheese & 6.6 & Bannock & 3.5 & Potatoes & 3.7 & $\begin{array}{l}\text { Fish and } \\
\text { shellfish }\end{array}$ & 3.5 & $\begin{array}{l}\text { Sweetened } \\
\text { beverages }\end{array}$ & 3.4 & Pasta and Rice & $3 \cdot 3$ & Sauces and condiments & 4.8 \\
\hline & Mixtures (meat) & 3.4 & Beef & 3.3 & Poultry & 3.6 & $\begin{array}{l}\text { Seal and } \\
\text { walrus }^{*}\end{array}$ & 3.5 & Mixtures (meat) & 3.4 & Poultry & 3.2 & Salt & $4 \cdot 3$ \\
\hline & Coffee and tea & $2 \cdot 8$ & Beluga whale* & $3 \cdot 2$ & Pasta and rice & 3.4 & Poultry & 3.3 & Fish and shellfish & $3 \cdot 3$ & Eggs & 3.0 & Poultry & 4.1 \\
\hline & Eggs & $2 \cdot 6$ & Mixtures (meat) & 3.1 & Potato chips & $3 \cdot 3$ & Pork & $3 \cdot 3$ & Pasta and Rice & 3.1 & Fish $^{*}$ & 3.0 & $\begin{array}{l}\text { Vegetables (sauce and } \\
\text { soup) }\end{array}$ & 3.8 \\
\hline & Fish $^{*}$ & $2 \cdot 1$ & $\begin{array}{l}\text { Sweetened } \\
\text { beverages }\end{array}$ & $2 \cdot 3$ & $\begin{array}{l}\text { Vegetables } \\
\text { (solid) }\end{array}$ & 3.1 & Mixtures (meat) & $2 \cdot 9$ & Berries* & $2 \cdot 9$ & Pork & $2 \cdot 7$ & Crackers and other & 3.5 \\
\hline \multirow{11}{*}{$\begin{array}{l}\text { Inuvialuit Settlement Region } \\
\text { (n 267) }\end{array}$} & Total (mg) & 600 & Total (mg) & 18 & Total (mg) & 282 & Total (g) & 16 & Total (mg) & 1 & Total (mg) & 253 & Total $(\mathrm{mg})$ & 3128 \\
\hline & $\begin{array}{l}\text { Sweetened } \\
\text { beverages }\end{array}$ & $14 \cdot 4$ & Caribou $^{*}$ & $22 \cdot 0$ & Coffee and tea & $10 \cdot 3$ & Caribou* & 24.4 & Caribou* $^{*}$ & $19 \cdot 3$ & Mixtures (grain) & 29.7 & Mixtures (grain) & $14 \cdot 3$ \\
\hline & Mixtures (grain) & 10.5 & Bread & 11.5 & Bread & 9.3 & Beef & 11.7 & Bread & $7 \cdot 2$ & Beluga whale* & $21 \cdot 7$ & Bread & $10 \cdot 8$ \\
\hline & Bread & $10 \cdot 2$ & Cereals & 7.5 & Fish $^{*}$ & 7.9 & Beluga whale* & 9.2 & Mixtures (grain) & 6.6 & Bread & $7 \cdot 1$ & Broths and gravy & $7 \cdot 2$ \\
\hline & Milk & 9.8 & Mixtures (grain) & 6.8 & Caribou* & 7.7 & $\begin{array}{l}\text { Fish and } \\
\text { shellfish }\end{array}$ & 5.3 & Fish and shellfish & 5.4 & Fish $^{*}$ & 5.9 & Processed meat & $6 \cdot 4$ \\
\hline & Cheese & 8.6 & Birds $^{*}$ & 5.5 & Mixtures (grain) & $5 \cdot 8$ & Bread & 4.4 & Fish $^{*}$ & 4.9 & Poultry & 4.6 & $\begin{array}{l}\text { Vegetables (sauce and } \\
\text { soup) }\end{array}$ & 5.9 \\
\hline & Bannock & 4.8 & Beef & 4.7 & Cereals & 4.8 & Pork & 4.3 & Birds* & 4.5 & Pork & 3.8 & Poultry & 4.1 \\
\hline & Fish $^{*}$ & 2.9 & Fish $^{*}$ & 3.3 & Poultry & 4.0 & Poultry & 3.9 & Potatoes & 4.5 & Pasta and Rice & 3.7 & Mixtures (meat) & 3.8 \\
\hline & Water & $2 \cdot 8$ & Beluga whale* & 3.1 & Potatoes & 3.7 & Mixtures (grain) & 3.9 & $\begin{array}{l}\text { Sweetened } \\
\text { beverages }\end{array}$ & 4.3 & Eggs & 3.6 & Sauces and condiments & 3.5 \\
\hline & Eggs & $2 \cdot 7$ & Pasta and Rice & $2 \cdot 8$ & Pasta and Rice & 3.1 & Fish $^{*}$ & 3.3 & Cereals & $3 \cdot 0$ & $\begin{array}{l}\text { Fish and } \\
\text { shellfish }\end{array}$ & 2.9 & Crackers and other & $3 \cdot 2$ \\
\hline & Coffee and tea & $2 \cdot 4$ & Poultry & $2 \cdot 8$ & $\begin{array}{l}\text { Vegetables } \\
\text { (solid) }\end{array}$ & $3 \cdot 1$ & Birds ${ }^{*}$ & 2.5 & Pasta and Rice & $3 \cdot 0$ & Caribou* $^{*}$ & $2 \cdot 7$ & Pork & $3 \cdot 0$ \\
\hline \multirow{11}{*}{$\begin{array}{l}\text { Nunatsiavut } \\
\quad(n \text { 260) }\end{array}$} & Total (mg) & 532 & Total (mg) & 15 & Total (mg) & 250 & Total (g) & 12 & Total (mg) & 1 & Total (mg) & 117 & Total (mg) & 2782 \\
\hline & Milk & $25 \cdot 3$ & Caribou* $^{*}$ & 14.3 & Bread & 9.6 & Caribou $^{*}$ & $17 \cdot 7$ & Caribou* $^{*}$ & $12 \cdot 1$ & Bread & $15 \cdot 7$ & Bread & 12.4 \\
\hline & Bread & $11 \cdot 0$ & Bread & 14.2 & Coffee and tea & $8 \cdot 2$ & Beef & $16 \cdot 4$ & Potatoes & 8.9 & Poultry & $10 \cdot 9$ & Processed meat & 9.7 \\
\hline & Cheese & $7 \cdot 3$ & Seal and walrus ${ }^{\star}$ & $6 \cdot 6$ & Potato chips & $7 \cdot 1$ & Poultry & 8.9 & Bread & 7.6 & $\begin{array}{l}\text { Fish and } \\
\text { shellfish }\end{array}$ & $10 \cdot 4$ & Broths and gravy & 8.6 \\
\hline & Mixtures (grain) & 6.8 & Cereals & $6 \cdot 1$ & Potatoes & 5.9 & Pork & 6.3 & Potato chips & 6.2 & Pork & 8.6 & Mixtures (grain) & 8.5 \\
\hline & $\begin{array}{l}\text { Sweetened } \\
\text { beverages }\end{array}$ & $6 \cdot 1$ & Birds* & 5.8 & & $5 \cdot 0$ & Bread & 4.9 & Beef & $6 \cdot 1$ & Pasta and Rice & $7 \cdot 8$ & Mixtures (meat) & 1 \\
\hline & Vegetables (solid) & 3.2 & Beef & 5.5 & Fruit (juice) & 4.9 & Mixtures (meat) & 4.5 & Fish and shellfish & $5 \cdot 1$ & Eggs & 7.1 & Potato chips & 5.6 \\
\hline & Fish and shellfish & $2 \cdot 9$ & Mixtures (grain) & 4.6 & Caribou* $^{*}$ & 4.8 & Milk & 3.8 & Birds* & 4.5 & Mixtures (grain) & 5.9 & Beef & 3.9 \\
\hline & Mixtures (meat) & $2 \cdot 8$ & Poultry & 4.3 & $\begin{array}{l}\text { Fish and } \\
\text { shellfish }\end{array}$ & 4.8 & $\begin{array}{l}\text { Processed } \\
\text { meat }\end{array}$ & 3.7 & Mixtures (meat) & 4.4 & Beef & 5.8 & $\begin{array}{l}\text { Vegetables (sauce and } \\
\text { soup) }\end{array}$ & 3.9 \\
\hline & Fruit (juice) & $2 \cdot 7$ & Mixtures (meat) & 4.2 & Poultry & 4.7 & Mixtures (grain) & 3.6 & Mixtures (grain) & 4.1 & Fish $^{*}$ & 4.7 & Fish and shellfish & 3.7 \\
\hline & Eggs & $2 \cdot 6$ & Pasta and Rice & 3.0 & Mixtures (grain) & 3.8 & $\begin{array}{l}\text { Fish and } \\
\text { shellfish }\end{array}$ & $3 \cdot 1$ & Poultry & 3.9 & $\begin{array}{l}\text { Processed } \\
\text { meat }\end{array}$ & 4.2 & Pork & 3.5 \\
\hline
\end{tabular}




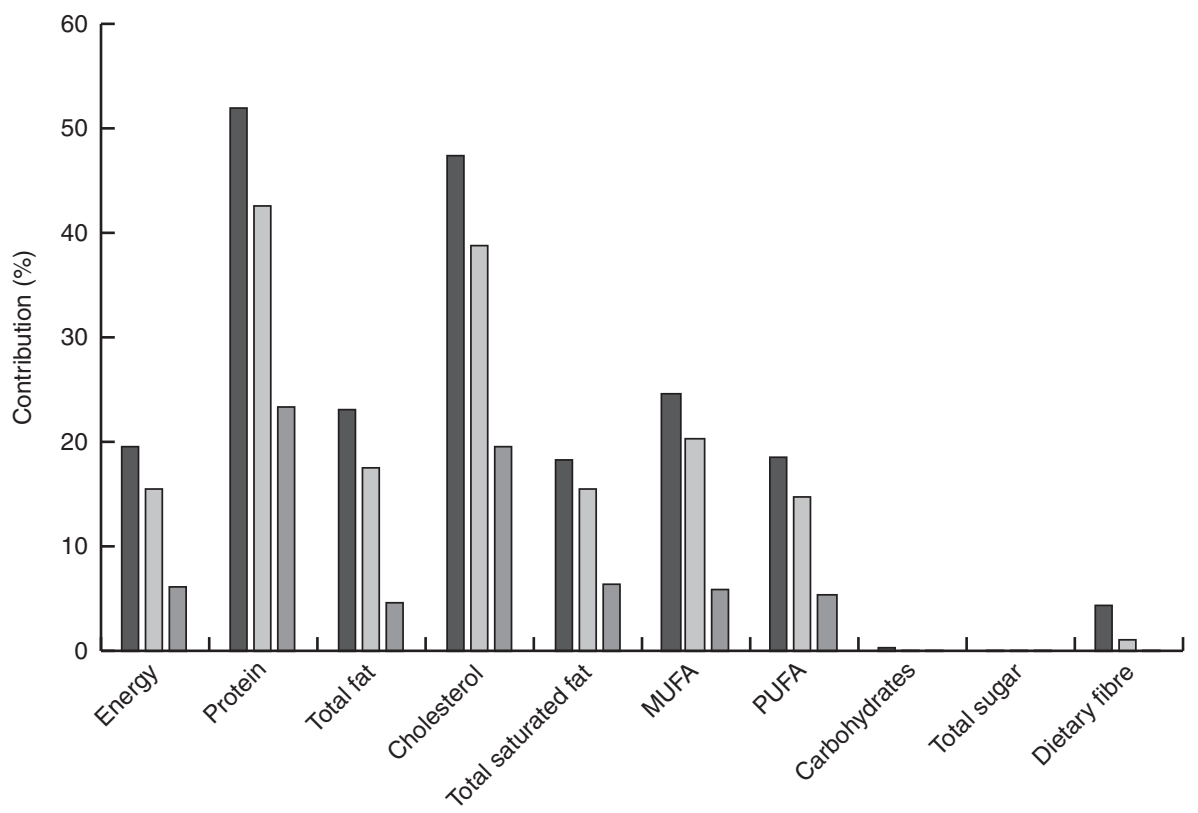

Fig. 2 Percentage contribution of country foods to daily energy, macronutrient and dietary fibre intakes among Inuit adults ( $n$ 2095), by region ( $\square$, Nunavut; $\square$, Inuvialuit Settlement Region; $\square$, Nunatsiavut); Inuit Health Survey 2007-2008

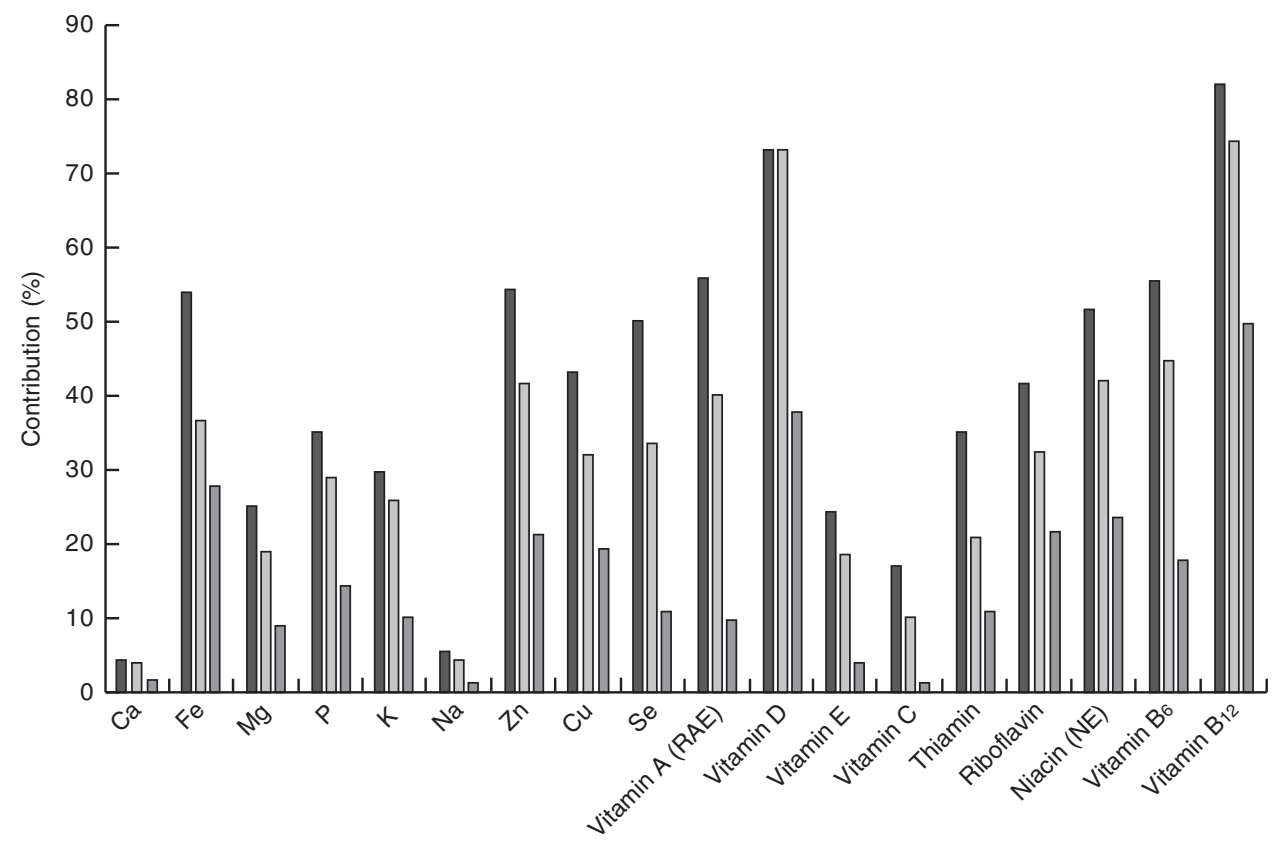

Fig. 3 Percentage contribution of country foods to micronutrient intakes among Inuit adults ( $n$ 2095), by region ( $\square$, Nunavut; $\square$, Inuvialuit Settlement Region; $\square$, Nunatsiavut); Inuit Health Survey 2007-2008 (RAE, retinol activity equivalents; NE, niacin equivalents)

contributed less than $20 \%$ of total Ca intake in the diet of Inuit adults in Nunavut and the ISR. Country foods are an extremely rich source of $\mathrm{Ca}$. Whereas one cup $(250 \mathrm{ml})$ of semi-skimmed milk contains $309 \mathrm{mg} \mathrm{Ca}$, a $100 \mathrm{~g}$ portion of baked whitefish, raw sculpin, raw fireweed leaves and raw arctic char skin contains 544, 429, 429 and $268 \mathrm{mg} \mathrm{Ca}$, respectively ${ }^{(35)}$. Likewise, there are many vitamin C-rich country foods, including local berries, fish eggs, muktuk, caribou liver and ringed seal liver ${ }^{(52)}$.
Dietary recommendations based on the promotion of country foods must, however, judiciously evaluate the risks associated with the presence of environmental contaminants (e.g. $\mathrm{Hg}$ and persistent organic pollutants) in these foods ${ }^{(53)}$. Furthermore, the diets of Indigenous Peoples, including the species/parts consumed, and the modes of food preparation (e.g. raw, cooked, fermented, dried) represent an articulation of culture and identity that embodies the multigenerational knowledge and experience 
of humans with local environments ${ }^{(5,54)}$. For Inuit, diet selection, health and cultural identity are embedded in various facets of the food system, including the relationship between animals and humans; the relationship between the body and the soul; and life and health ${ }^{(11)}$. While traditional Arctic food systems are comprised of a rich micronutrient base, provided by a diversity of plant species and animal parts ${ }^{(5)}$, use of country food species' organs in the current study, consistent with previous literature ${ }^{(5)}$, was very inadequate (less than $2 \%$ of participants). The decreased use of micronutrient-rich animal parts, coupled with the broader pattern of substituting country foods with micronutrient-poor market foods, poses considerable risk of inadequate nutrition in Inuit communities ${ }^{(5)}$.

While dietary variations exist both between and within Inuit communities and regions, these results offer a broad perspective on Inuit dietary trends across the Canadian north. Results from our study are very similar to those reported in dietary assessments involving a more restricted community (or multiple-community) focus ${ }^{(44,48,55)}$. For example, our results are very similar to those previously reported by Sharma et al. $(2010,2013)$ for adults in Nunavut, whereby non-nutrient-dense foods contributed $30 \%$ of energy, $73 \%$ of sugars and $22 \%$ of fat, while country foods contributed $56 \%$ of protein and $49 \%$ of $\mathrm{Fe}^{(9,48)}$. While local knowledge is requisite to the development of health promotion programmes in the north ${ }^{(56)}$, programmes and policies aimed at mitigating food insecurity and promoting healthy diets may operate at broader scales (e.g. Nutrition North Canada retailer food subsidy). Likewise, external food system drivers, such as climate change, may occur and be modelled by scientists at broader scales ${ }^{(21)}$. Targeted food security interventions are often implemented at local levels. They are often ad hoc and based on limited available data. Regional-level data are essential for informing the development of broader policies which are effectuated and administered at this scale.

Although the intent of the present study was not to compare region-level differences in diets, we observed variations in the consumption of a few market food items (i.e. fluid milk $v$. powdered milk and coffee whitener, as well as fruit juice $v$. sugar-sweetened beverages) and country foods (i.e. marine mammals) between the eastern and western Arctic. Given the differential access to marine mammals and marine fish between coastal and inland communities, results from the present study, aggregated by administrative region, may have confounded important geographic differences in dietary patterns. Marine foods are rich sources of highly unsaturated fatty acids, and Zhou et al. (2011) have previously reported pronounced regional differences in the fatty acid composition of erythrocyte membranes between coastal Inuit and inland Inuit, suggesting distinct dietary intake patterns across the north ${ }^{(26)}$. While the present study suggests a modest contribution of country foods to PUFA (derived principally from caribou and local fish), given the seasonality of country food consumption, results from the study must be interpreted with caution. This highlights the importance of integrating results from dietary assessments, food composition analysis and biomarkers of human nutritional status/contaminant exposure within a sociocultural and ecological sampling framework.

\section{Limitations}

The many limitations inherent to the assessment of diet by $24 \mathrm{~h}$ recall must be acknowledged ${ }^{(57)}$. Validity of the $24 \mathrm{~h}$ recall is contingent upon the respondents' ability to recall all foods consumed and to estimate portion sizes accurately ${ }^{(57)}$. Use of the USDA Automated Multiple-Pass Method in the present study is likely to have mitigated response bias and has been validated in other populations as an accurate measure of energy and nutrients at the group level ${ }^{(30)}$. As results from the present study are based on a single $24 \mathrm{~h}$ recall for each participant, results for the contribution of specific food groups to total energy intake must be interpreted with caution. The exclusion of alcohol and nutrient supplements in the present study may have resulted in an underestimation of total energy and nutrient intakes. Nevertheless, less than $10 \%$ of participants of the IHS reported using vitamins and dietary supplements (IHS, unpublished results). As the $24 \mathrm{~h}$ recall was collected during a single season, results of country food consumption reflect species harvest and availability during the study period (late summer-autumn) and may differ through the year. The importance of recognizing the variability in seasonal food use in Indigenous Peoples' food systems has been previously highlighted ${ }^{(40)}$. Finally, the strong cultural bias towards country foods may have affected reporting rates reported in the present study.

\section{Conclusion}

Consistent with long-held local knowledge, results from the present study highlight that country foods, given their rich nutrient profiles and cultural favourability, should be prioritized within strategies to promote nutrient adequacy among Inuit. Such strategies, however, must account for the human health risks of contaminant exposure and respect the ecological limits of harvest sustainability - as determined by both traditional/local knowledge and the strongest available science. Furthermore, promoting Inuit health and food security through the consumption of country foods necessitates broader ecological frameworks to support the environment and sensitive habitats of country food species. However, the present study also highlights the importance of market foods in the contemporary Inuit food system. Ultimately, policies and programmes aimed at fostering dietary adequacy and food security among Inuit should be predicated upon community-identified priorities and should affirm Indigenous food sovereignty and self-determination. 


\section{Acknowledgements}

Acknowledgements: The authors wish to recognize and extend their appreciation to all participating community members, community and health organizations, nurses, technicians, Drs Grace Egeland and Kue Young, and the Steering Committees of the Canadian International Polar Year IHS. They gratefully acknowledge the National Inuit Health Survey Working Group for reviewing this manuscript and providing invaluable feedback; and extend thanks to Rita Kluktka (Health Canada) for assistance with the CNF. Financial support: The IHS was realized with funding from the Government of Canada Federal Program for International Polar Year, the Canadian Institutes of Health Research, Health Canada, the Northern Contaminant Program of the Government of Canada, ArcticNet, the Canada Research Chair Program and the Canadian Foundation for Innovation. The funders had no role in the design, analysis or writing of this article. Conflict of interest: None to declare. Authorship: T.-A.K. conducted the analyses, interpreted the data and drafted the manuscript. X.F.H. provided guidance on the interpretation of the results and input on the drafted manuscript. H.V.K. contributed to survey design and data collection, and interpretation of the study results. S.D.W. and H.M.C. guided the research and revised the drafted manuscript. Ethics of buman subject participation: The survey was developed in a participatory manner, with steering committees representing the participating Inuit jurisdictions. A Certificate of Ethical Acceptability for the IHS was granted by the McGill Faculty of Medicine Institutional Review Board. Scientific Research Licences were obtained from relevant northern research granting institutions (Aurora Research Institute, Nunavut Research Institute). Ethical clearance for secondary analysis of data was granted by the University of Ottawa Health Sciences and Science Research Ethics Board (file number H05-15-16). Informed written consent was obtained from all participants.

\section{Supplementary material}

To view supplementary material for this article, please visit https://doi.org/10.1017/S1368980017003810

\section{References}

1. Popkin BM (1998) The nutrition transition and its health implications in lower-income countries. Public Health Nutr 1, 5-21.

2. Popkin BM \& Gordon-Larsen P (2004) The nutrition transition: worldwide obesity dynamics and their determinants. Int J Obes Relat Metab Disord 28, S2-S9.

3. Albala C, Vio F, Kain J et al. (2002) Nutrition transition in Chile: determinants and consequences. Public Health Nutr 5, 123-128.
4. Port Lourenco AE, Santos RV, Orellana JDY et al. (2008) Nutrition transition in Amazonia: obesity and socioeconomic change in the Surui Indians from Brazil. Am J Hum Biol 20, 564-571.

5. Kuhnlein HV, Receveur O, Soueida R et al. (2004) Arctic Indigenous Peoples experience the nutrition transition with changing dietary patterns and obesity. J Nutr 134, 1447-1453.

6. Hughes RG \& Lawrence MA (2005) Globalisation, food and health in Pacific Island countries. Asia Pac J Clin Nutr 14, 298-305.

7. Bonesteel S \& Anderson E (2006) Canada's Relationship with Inuit: A History of Policy and Program Development. Ottawa: Indian and Northern Affairs Canada; available at https://www.aadnc-aandc.gc.ca/eng/1100100016900/110010 0016908

8. Akande VO, Hendriks AM, Ruiter RAC et al. (2015) Determinants of dietary behavior and physical activity among Canadian Inuit: a systematic review. Int J Behav Nutr Phys Act 12, 84 .

9. Sharma S, Cao X, Roache C et al. (2010) Assessing dietary intake in a population undergoing a rapid transition in diet and lifestyle: the Arctic Inuit in Nunavut, Canada. BrJ Nutr 103, 749-759.

10. Egeland GM, Johnson-Down L, Cao ZR et al. (2011) Food insecurity and nutrition transition combine to affect nutrient intakes in Canadian arctic communities. J Nutr 141, 1746-1753.

11. Borré K (1991) Seal blood, Inuit blood, and diet: a biocultural model of physiology and cultural identity. Med Anthropol Q 5, 48-62.

12. Searles E (2002) Food and the making of modern Inuit identities. Food Foodways 10, 55-78.

13. Pufall EL, Jones AQ, McEwen SA et al. (2011) Perception of the importance of traditional country foods to the physical, mental, and spiritual health of Labrador Inuit. Arctic 64, 242-250.

14. Schaefer SE, Erber E, Trzaskos JP et al. (2011) Sources of food affect dietary adequacy of Inuit women of childbearing age in Arctic Canada. J Health Popul Nutr 29, 454-464.

15. Jamieson JA, Weiler HA, Kuhnlein HV et al. (2012) Traditional food intake is correlated with iron stores in Canadian Inuit men. J Nutr 142, 764-770.

16. Power EM (2008) Conceptualizing food security for Aboriginal people in Canada. Can J Public Health 99, 95-97.

17. Sharma S (2010) Assessing diet and lifestyle in the Canadian Arctic Inuit and Inuvialuit to inform a nutrition and physical activity intervention programme. J Hum Nutr Diet 23, Suppl. 1, 5-17.

18. Erber E, Hopping BN, Beck L et al. (2010) Assessment of dietary adequacy in a remote Inuvialuit population. $J$ Hum Nutr Diet 23, 35-42.

19. Sheikh N, Egeland GM, Johnson-Down L et al. (2011) Changing dietary patterns and body mass index over time in Canadian Inuit communities. Int J Circumpolar Health $\mathbf{7 0}$, $511-519$

20. Gionet L \& Roshanafshar S (2013) Select Health Indicators of First Nations People Living off Reserve, Métis and Inuit. Ottawa: Statistics Canada; available at https://www.statcan. gc.ca/pub/82-624-x/2013001/article/11763-eng.htm

21. Wesche SD \& Chan HM (2010) Adapting to the impacts of climate change on food security among Inuit in the Western Canadian Arctic. EcoHealth 7, 361-373.

22. Government of Canada (2016) Performance Measurement Strategy. (4.1.2) Nutrition North Canada. https://www.aadncaandc.gc.ca/DAM/DAM-INTER-HQ-AI/STAGING/texte-text/ pm_nnna16_1490793720185_eng.pdf (accessed January 2018).

23. Nunavut Food Security Coalition (2014) Nunavut Food Security Strategy and Action Plan 2014-16. http://www.nunavut foodsecurity.ca/sites/default/files/files/Resources/Strategy/ NunavutFoodSecurityStrategy_ENGLISH.pdf (accessed December 2017). 
24. Kuhnlein HV, Receveur O, Soueida R et al. (2008) Unique patterns of dietary adequacy in three cultures of Canadian Arctic indigenous peoples. Public Health Nutr 11, 349-360.

25. Galloway T, Johnson-Down L \& Egeland GM (2015) Socioeconomic and cultural correlates of diet quality in the Canadian Arctic: results from the 2007-2008 Inuit Health Survey. Can J Diet Pract Res 76, 117-125.

26. Zhou YE, Kubow S \& Egeland GM (2011) Highly unsaturated $n$-3 fatty acids status of Canadian Inuit: International Polar Year Inuit Health Survey, 2007-2008. Int J Circumpolar Health 70, 498-510.

27. Huet C, Rosol R \& Egeland GM (2012) The prevalence of food insecurity is high and the diet quality poor in Inuit communities. J Nutr 142, 541-547.

28. Rochette L \& Blanchet C (2007) Nunavik Inuit Health Survey 2004, Qanuippitaa? How are We? - Methodological Report. Québec: Institut national de santé publique du Québec and Nunavik Regional Board of Health and Social Services.

29. Saudny H, Leggee D \& Egeland GM (2012) Design and methods of the Adult Inuit Health Survey 2007-2008. Int J Circumpolar Health 71, 19752.

30. Blanton CA, Moshfegh AJ, Baer DJ et al. (2006) The USDA automated multiple-pass method accurately estimates group total energy and nutrient intake. J Nutr 136, 2594-2599.

31. Direction de Santé Québec, Institut de la Statistique du Québec (2013) Food Models. Montréal: Institut de la Statistique du Québec.

32. Guenther PM, Kott PS \& Carriquiry AL (1997) Development of an approach for estimating usual nutrient intake distributions at the population level. J Nutr 127, 1106-1112.

33. Ahuja JKA, Montville JB, Omolewa-Tomobi G et al. (2012) The USDA Food and Nutrient Database for Dietary Studies, 5.0 - Documentation and User Guide. Beltsville, MD: US Department of Agriculture, Agricultural Research Service, Food Surveys Research Group.

34. Canadian Food Inspection Agency (2014) Reference Information: Foods to Which Vitamins, Mineral Nutrients and Amino Acids May or Must be Added. Food and Drug Regulations (D.03.002). http://www.inspection.gc.ca/food/ labelling/food-labelling-for-industry/nutrient-content/referenceinformation/eng/1389908857542/1389908896254?chap=1 (accessed January 2017).

35. Health Canada (2015) Canadian Nutrient File (CNF), 2015. Ottawa: Food Directorate, Nutrition Research Division.

36. Schakel SF, Buzzard IM \& Gebhardt SE (1997) Procedures for estimating nutrient values for food composition databases. I Food Compost Anal 10, 102-114.

37. Montville JB, Ahuja JKC, Martin CL et al. (2013) USDA Food and Nutrient Database for Dietary Studies (FNDDS), 5.0. Procedia Food Sci 2, 99-112.

38. Krebs-Smith SM, Kott PS \& Guenther PM (1989) Mean proportion and population proportion: two answers to the same question? J Am Diet Assoc 89, 671-676.

39. Block G, Dresser CM, Hartman AM et al. (1985) Nutrient sources in the American diet: quantitative data from the NHANES II survey II. Macronutrients and fats. Am J Epidemiol 122, 27-40.

40. Kuhnlein HV (1995) Benefits and risks of traditional food for Indigenous Peoples: focus on dietary intakes of Arctic men. Can J Physiol Pharmacol 73, 765-771.
41. Kuhnlein HV \& Chan LH (2000) Environment and contaminants in traditional food systems of northern indigenous peoples. Annu Rev Nutr 20, 595-626.

42. Kuhnlein HV \& Receveur O (1996) Dietary change and traditional food systems of indigenous peoples. Annu Rev Nutr 16, 417-442.

43. Kuhnlein HV, Chan HM, Leggee D et al. (2002) Macronutrient, mineral and fatty acid composition of Canadian arctic traditional food. J Food Compost Anal 15, 545-566.

44. Hopping BN, Mead E, Erber E et al. (2010) Dietary adequacy of Inuit in the Canadian Arctic. J Hum Nutr Diet 23, Suppl. 1, 27-34.

45. Duhaime G, Chabot M \& Gaudreault M (2002) Food consumption patterns and socioeconomic factors among the Inuit of Nunavik. Ecol Food Nutr 41, 91-118.

46. Lambden J, Receveur O \& Kuhnlein HV (2007) Traditional food attributes must be included in studies of food security in the Canadian Arctic. Int J Circumpolar Health 66, 308-319.

47. Johnson-Down L \& Egeland GM (2010) Adequate nutrient intakes are associated with traditional food consumption in Nunavut Inuit children aged 3-5 years. $J$ Nutr 140, 1311-1316.

48. Sharma S, Hopping BN, Roache C et al. (2013) Nutrient intakes, major food sources and dietary inadequacies of Inuit adults living in three remote communities in Nunavut, Canada. J Hum Nutr Diet 26, 578-586.

49. Zienczuk N, Young TK, Cao ZR et al. (2012) Dietary correlates of an at-risk BMI among Inuit adults in the Canadian high arctic: cross-sectional international polar year Inuit health survey, 2007-2008. Nutr J 11, 73.

50. Heaney RP \& Rafferty K (2006) The settling problem in calcium-fortified soybean drinks. J Am Diet Assoc 106, $1753-1753$.

51. Johnson-Down L, Ritter H, Starkey LJ et al. (2006) Primary food sources of nutrients in the diet of Canadians. Can J Diet Pract Res 67, 7-13.

52. Fediuk K, Hidiroglou N, Madère R et al. (2002) Vitamin C in Inuit traditional food and women's diets. J Food Compost Anal 15, 221-235.

53. Laird BD, Goncharov AB, Egeland GM et al. (2013) Dietary advice on Inuit traditional food use needs to balance benefits and risks of mercury, selenium, and $\mathrm{n} 3$ fatty acids. J Nutr 143, 923-930.

54. Kuhnlein HV \& Receveur O (2007) Local cultural animal food contributes high levels of nutrients for Arctic Canadian Indigenous adults and children. J Nutr 137, $1110-1114$.

55. Blanchet C \& Rochette L (2008) Nutrition and Food Consumption Among the Inuit of Nunavik. Québec: Institut national de santé publique du Québec and Nunavik Regional Board of Health and Social Services.

56. Bjerregaard P (2010) Nutritional transition - where do we go from here? J Hum Nutr Diet 23, Suppl. 1, 1-2.

57. Shim J-S, Oh K \& Kim HC (2014) Dietary assessment methods in epidemiologic studies. Epidemiol Health 36, e2014009. 